\title{
A Review of Murine Cytomegalovirus as a Model for Human Cytomegalovirus Disease-Do Mice Lie?
}

\author{
Michelle A. Fisher ${ }^{1}$ and Megan L. Lloyd ${ }^{1,2, * \mathbb{D}}$ \\ 1 Division of Infection and Immunity, School of Biomedical Sciences, The University of Western Australia, \\ Nedlands 6009, Australia; michelle.fisher@uwa.edu.au \\ 2 Marshall Centre for Infectious Diseases Research and Training, Division of Infection and Immunity, \\ School of Biomedical Sciences, The University of Western Australia, Nedlands 6009, Australia \\ * Correspondence: megan.lloyd@uwa.edu.au
}

check for

updates

Citation: Fisher, M.A.; Lloyd, M.L. A Review of Murine Cytomegalovirus as a Model for Human

Cytomegalovirus Disease-Do Mice Lie?. Int. J. Mol. Sci. 2021, 22, 214 https://doi.org/10.3390/ijms22010214

Received: 8 November 2020 Accepted: 17 December 2020 Published: 28 December 2020

Publisher's Note: MDPI stays neutral with regard to jurisdictional claims in published maps and institutional affiliations.

Copyright: () 2020 by the authors. Licensee MDPI, Basel, Switzerland. This article is an open access article distributed under the terms and conditions of the Creative Commons Attribution (CC BY) license (https: / / creativecommons.org/ licenses/by/4.0/).

\begin{abstract}
Since murine cytomegalovirus (MCMV) was first described in 1954, it has been used to model human cytomegalovirus (HCMV) diseases. MCMV is a natural pathogen of mice that is present in wild mice populations and has been associated with diseases such as myocarditis. The species-specific nature of HCMV restricts most research to cell culture-based studies or to the investigation of non-invasive clinical samples, which may not be ideal for the study of disseminated disease. Initial MCMV research used a salivary gland-propagated virus administered via different routes of inoculation into a variety of mouse strains. This revealed that the genetic background of the laboratory mice affected the severity of disease and altered the extent of subsequent pathology. The advent of genetically modified mice and viruses has allowed new aspects of disease to be modeled and the opportunistic nature of HCMV infection to be confirmed. This review describes the different ways that MCMV has been used to model HCMV diseases and explores the continuing difficulty faced by researchers attempting to model HCMV congenital cytomegalovirus disease using the mouse model.
\end{abstract}

Keywords: congenital disease; placenta; salivary gland

\section{Introduction}

It has famously been stated that "mice lie and monkeys exaggerate" [1], but the use of animal models in the study of infectious disease provides strong evidence for the mechanisms underlying the pathogenesis of infections in humans and provides opportunities to study interactions between hosts and pathogens that are not provided by collecting minimally invasive human samples such as blood, feces, saliva and urine. When investigating infectious diseases, the ability to correlate tissue histopathology with pathogen replication rates over time or evaluate cell signaling and related immune modulation in the context of a complete immune system is of inestimable value and provides mechanistic information, as well as pre-clinical opportunities to test treatment efficacy and toxicity. The ability of a pathogen to infect both mice and humans allowed the development of Koch's postulates [2], an evidence framework still used today to prove the association of newly described pathogens with infection and subsequent pathological sequelae, albeit with modifications to account for the presence of pathogens in commensal flora [3] and viruses that are attenuated in a culture [4]. An example of this modern reasoning has been applied for SARS-CoV-1 [5].

There are many animal models where laboratory-inoculated animals exhibit symptoms or pathogen replication that mimics human infection, even though infection may not occur in the natural environment. These models are useful in carefully evaluated (and disclosed) circumstances (discussed in [6] for SARS-CoV-2) and have provided useful information on infection pathways and the effects of opportunistic infections and potential drug targets [7]. Examples of animal models in non-target species are those developed for influenza and 
respiratory syncytial virus in ferrets [8] and Ebola virus infection, which have been modeled in suckling (but not adult) immunocompetent mice as well as Syrian golden hamsters [9]. These models and others like them have illuminated pathways used by pathogens to travel from the site of infection to organs or other sites of tropism, as well as immune responses, symptom and infection profiles and treatment options.

In animal models for viral disease, the presence of the correct receptor used by the virus to enter a cell is critical and needs to be largely conserved between species for crossspecies infection to occur [6]. For infections where viruses do not naturally infect another species due to absence of the correct receptor, transgenic mice have been developed that allow an animal model to be developed (e.g., for poliovirus) [10]. Some viruses, such as influenza, naturally infect multiple species (avian species, pigs and humans [11]) while others, such as cytomegalovirus, are species-specific. Animal models where the pathogen naturally infects the animal host and the disease is naturally present in wild populations can provide insights into human disease by illuminating complex host-pathogen interactions and provide clinically relevant data.

Cytomegaloviruses (CMVs) from the family Herpesviridae and the subfamily Betaherpesvirinae are species-specific viruses and have been isolated from many mammalian species (e.g., human, mouse, rat, guinea pig and various primates; see [12] for a discussion). CMVs have evolved with their hosts [13] and generally do not replicate completely in vivo in different species after inoculation, even where in vitro growth has been described (e.g., murine cytomegalovirus (MCMV) will grow in vitro in rat cells but will not grow in vivo in rats [14]). However, there have been reports of the replication of disparate CMV in other species in circumstances where xenotransplantation has taken place and the recipient has received immunosuppressive chemotherapy $[15,16]$. Juvenile rats have also been reported to support the growth of MCMV, although older rats ( $>6$ weeks old) were not susceptible to infection [17]. This review will focus on the use of MCMV to model human cytomegalovirus (HCMV) disease.

\section{Murine Cytomegalovirus Infection as a Model for Human Cytomegalovirus Disease}

MCMV infecting its murine host has been used extensively to model human disease with HCMV [18]. MCMV is a natural pathogen of mice, being found in every wild Mus musculus population that has been investigated in Australia (for example, those found in $[19,20])$. There are many genetic similarities between HCMV and MCMV with multiple gene homologs, including structural and immune-evasion genes [21]. However, there are important differences in the organization of the genetic information. For example, HCMV has unique long and unique short regions with terminal and internal repeat sequences [22] compared with MCMV, which has a single unique sequence with short terminal direct repeats and several short internal repeats [21]. Additionally, the adaptation of these viruses to cell culture is different, as the in vitro culture of clinical isolates of HCMV invariably leads to the predictable loss of genetic regions (discussed in [23]) that does not occur to the same extent with MCMV [24], although a recent report has provided evidence that deletions occur as MCMV is propagated from salivary glands in culture [25].

\subsection{Properties of Salivary Gland-Derived and Tissue Culture-Passaged MCMV}

Modeling HCMV infection with MCMV with the use of virus stocks prepared from different sources is complicated. MCMV is generally maintained either as salivary gland stock (SGV) or as tissue culture-derived stock (TCV), usually prepared from the infection of embryonic mouse fibroblasts [26]. This influences the nature of the infection that occurs in vivo [27]. SGV is generally composed of single capsid virions, derived from the cytoplasmic vacuoles within the serous acinar sinus cells of the salivary gland [28]. It produces acute infection in mice, is lethal when inoculated at a relatively low titer in juvenile (3-week-old) mice and has been used in Lethal Dose ${ }_{50}\left(\mathrm{LD}_{50}\right)$ studies to demonstrate innate major histocompatibility $(\mathrm{MCH})$ associated resistance to MCMV in various inbred mouse strains $[29,30]$. In contrast, virus stocks made from other organs (e.g., the liver and 
spleen) and also TCV passaged in embryonic mouse fibroblasts are comprised of both single and multicapsid virions [31]. TCV is generally not lethal, unless the mouse strain has a substantial immune deficiency (e.g., severe combined immuno-deficient mice that do not have B or T cells can be lethally infected with 1 plaque-forming unit (PFU) of SGV [32]).

\subsection{MCMV as a Model for HCMV Infection}

The recorded movement of MCMV between organs differs, depending on the route of infection (described in [33] and [12]). There is a strong tropism for the salivary gland, and active viral replication persists in salivary glands for longer than other organs, regardless of the route of infection used. As with all herpesviruses, MCMV infection has a latent phase [32]. MCMV infection without significant manipulation of the host has successfully been used to model various aspects of human infection (Table 1). Information from this natural animal model has greatly improved the understanding of the pathogenesis of HCMV infection in humans.

Table 1. Human disease caused by human cytomegalovirus (HCMV) modeled by murine cytomegalovirus (MCMV) infection in mice.

\begin{tabular}{|c|c|c|c|c|}
\hline Human Condition & Lab Conditions & $\begin{array}{c}\mathrm{SGV}^{1 / \mathrm{TCV}^{2}} \\
\mathrm{PFU}^{3}\end{array}$ & Effect & Reference \\
\hline Viremia & $\begin{array}{l}\text { Intraperitoneal (i.p) } \\
\text { inoculation of } \\
\text { BALB/cByJ mice. }\end{array}$ & $\begin{array}{l}\text { SGV /TCV not } \\
\text { specified } \\
10^{6} \mathrm{PFU}\end{array}$ & $\begin{array}{l}\text { White blood cells have viral } \\
\text { DNA but no evidence of } \\
\text { ie1 RNA. }\end{array}$ & [34] \\
\hline Viral latency & $\begin{array}{c}\text { BALB/c footpad inoculated } \\
\text { at } 2 \text { weeks of age. Latency } \\
\text { present after } 3 \text { weeks. }\end{array}$ & $\begin{array}{c}\mathrm{TCV} \\
10^{5} \mathrm{PFU}\end{array}$ & $\begin{array}{l}\text { Whole body irradiation leads } \\
\text { to reactivation of infection. } \\
\text { Antibody protects from } \\
\text { viral dissemination. }\end{array}$ & {$[35,36]$} \\
\hline \multirow[t]{2}{*}{ Pneumonitis } & $\begin{array}{l}\text { 1. Intranasal inoculation into } \\
\text { outbred Swiss mice or } \\
\text { intra-tracheal infection of } \\
\text { BALB/c mice. }\end{array}$ & $\begin{array}{c}\text { TCV } \\
>10^{4} \mathrm{PFU}\end{array}$ & $\begin{array}{l}\text { Severe diffuse interstitial } \\
\text { pneumonitis closely } \\
\text { resembling that seen in } \\
\text { immunocompromised patients } \\
\text { and in newborn infants, } \\
20 \% \text { died. }\end{array}$ & [37] \\
\hline & $\begin{array}{l}\text { 2. Inoculation of newborn } \\
\text { BALB/c. }\end{array}$ & SGV, 6 PFU i.p. & $\begin{array}{l}\text { Pneumonitis and myocarditis, } \\
95 \% \text { lethal. }\end{array}$ & [38] \\
\hline Hepatitis & $\begin{array}{l}\text { i.p inoculation of } \\
\text { BALB/c mice. }\end{array}$ & $\mathrm{SGV}, 10^{5} \mathrm{PFU}$ & $\begin{array}{l}\text { Hepatitis evident, dose is } \\
\text { Lethal Dose } 50 .\end{array}$ & [26] \\
\hline \multirow{2}{*}{$\begin{array}{l}\text { Ocular infection } \\
\text { (retinitis) }\end{array}$} & \multirow{2}{*}{$\begin{array}{l}\text { 1. Intraocular inoculation } \\
\text { (scarified cornea or through } \\
\text { corneal limbus) of } \\
\text { IRC/Sic mice. } \\
\text { 2. Intraperitoneal inoculation } \\
\text { of BALB/c mice. }\end{array}$} & \multirow{2}{*}{$\begin{array}{l}\text { SGV, Tissue Culture } \\
\text { Infectious Dose } 50 \\
\text { values given. }\end{array}$} & Different effects SGV vs. TCV. & [39] \\
\hline & & & $\begin{array}{l}\text { Inflammatory response in } \\
\text { retina (virus not present) and } \\
\text { iris (virus present). }\end{array}$ & [40] \\
\hline $\begin{array}{l}\text { Excretion of CMV into } \\
\text { breastmilk }\end{array}$ & $\begin{array}{l}\text { Acute or latently inoculated } \\
\text { C57BL/ } 6 \text { mothers (i.p.), } \\
\text { leukocytes from BM positive } \\
\text { by ie1 mRNA } \\
\text { detection, RTPCR. }\end{array}$ & $\begin{array}{c}\mathrm{SGV} \\
3 \times 10^{2}-3 \times 10^{4} \mathrm{PFU}\end{array}$ & $\begin{array}{l}\text { Evidence of neonatal infection } \\
\text { via breast milk. Inoculation of } \\
\text { milk into CD-1 1-day old mice } \\
\text { results in infection. }\end{array}$ & [41] \\
\hline $\begin{array}{l}\text { Arterial blood pressure } \\
\text { post CMV infection }\end{array}$ & $\begin{array}{c}\text { i.p. inoculation of } \\
\text { 2-week-old C57BL/6 mice. }\end{array}$ & $\begin{array}{c}\mathrm{TCV} \\
3 \times 10^{5} \\
\mathrm{PFU} / 1 \mathrm{~mL} / \text { mouse }\end{array}$ & $\begin{array}{l}\text { MCMV increased blood } \\
\text { pressure independent of diet. } \\
\text { Increased serum IL-6, } \\
\text { TNF-alpha, and MCP-1. }\end{array}$ & [42] \\
\hline Viral myocarditis & $\begin{array}{l}\text { i.p. inoculation of } \\
\text { C57BL/ } 6 \text { and BALB/c mice. }\end{array}$ & $\begin{array}{l}\text { SGV } \\
10^{4} \mathrm{PFU}\end{array}$ & $\begin{array}{l}\text { Inflammatory foci in the heart } \\
\text { and infection of } \\
\text { cardiac myocytes. }\end{array}$ & [43] \\
\hline
\end{tabular}


Table 1. Cont.

\begin{tabular}{cccc}
\hline Human Condition & Lab Conditions & $\begin{array}{c}\text { SGV } \mathbf{1} / \mathbf{T C V}^{\mathbf{2}} \\
\text { PFU }^{\mathbf{3}}\end{array}$ & Effect \\
\hline $\begin{array}{c}\text { Infection post bone } \\
\text { marrow transplantation }\end{array}$ & $\begin{array}{c}\text { Irradiated BALB/c mice } \\
\text { inoculated with virus prior } \\
\text { to intravenous (i.v.) purified } \\
\text { bone marrow cells. }\end{array}$ & $10^{5} \mathrm{PFU}$ & $\begin{array}{c}\text { Failure in haematopoiesis, } \\
\text { leading to death. }\end{array}$ \\
\hline $\begin{array}{c}\text { Sexual transmission of } \\
\text { CMV via semen }\end{array}$ & $\begin{array}{c}\text { Spermatozoa plus Smith } \\
\text { MCMV artificially } \\
\text { inseminated (compared with } \\
\text { sperm alone) }\end{array}$ & $\begin{array}{c}\text { SGV } \\
10^{5} \text { PFU }\end{array}$ & $\begin{array}{c}\text { Embryos collected on E14. } \\
\text { One produced cytopathic } \\
\text { effect (second passage). } \\
\text { significant difference with } \\
\text { numbers or abnormalities. }\end{array}$ \\
\hline
\end{tabular}

${ }^{1}$ Salivary gland derived virus. ${ }^{2}$ Tissue culture-derived virus. ${ }^{3}$ Plaque-forming units.

\subsection{Mouse Strain Selection Affects the Severity of MCMV Pathogenesis}

Investigations of the effect of MCMV in different mouse strains have been pivotal in the modeling of different disease states. Initial work focused on $\mathrm{LD}_{50}$ calculations (e.g., [46]), and it was found that the H-2 alleles of different mouse strains determined their response to infection, including the production of autoantibodies [47] and the induction of myocarditis [48]. Other mechanisms for resistance to MCMV, such as that demonstrated in C57BL/6 mice compared with BALB/c mice or the differing resistance of New Zealand Black and White mice to MCMV infection, were associated with differences in innate natural killer (NK) cell activation and were strongly associated with particular strains of viruses [49,50]. Where MCMV was used as a vaccine vector expressing the mouse ovarian glycoprotein zona pellucida 3 in studies investigating immune-mediated contraception, the specific $\mathrm{m} 157$ (viral ligand) to $\mathrm{Ly} 49 \mathrm{H}$ (NK cell activation receptor) rapid response to infection was broadly associated with vaccine success [51]. This effect was abrogated through the use of a different virus strain, G4 (isolated from the salivary glands of a mouse from Geraldton, WA [52]), as the vaccine vector. G4 does not have the same interaction with NK cell activation receptors, and this demonstrates the importance of vector strain selection in the development of recombinant CMV-based vaccines [53].

\subsection{MCMV-Based Models for Human Disease Requiring Chemical, Genetic or Physical Manipulation}

A recent systematic review and metanalysis calculated that the worldwide seroprevalence of HCMV is $83 \%$ [54]. Increasing CMV disease is broadly associated with improvements in medicine because it is often associated with acute immunosuppression, allowing the reactivation of a latent infection. One of the more serious sequelae of CMV infection is found in solid organ transplant recipients, who often experience reactivation from latency and associated pneumonitis, hepatitis and potential organ rejection (discussed in [55]). The likelihood of severe CMV disease increases when the transplanted organ is from a seropositive donor (previously infected with $C M V$, with no active viral replication but a strong CMV-specific humoral response) being transplanted into a seronegative recipient [56]. In general, outcomes can be improved with the use of antiviral therapy, with a recent metanalysis suggesting that prophylactic treatment using low doses of valganciclovir provides improved outcomes in kidney transplant recipients [57]. CMV can also cause post-transplantation disease in recipients of allogeneic hematopoietic stem cell transplants, and pre-emptive therapy is often initiated after clinical evidence of CMV reactivation (prior to fulminant disease). The economic burden of this therapy is marked [58]. The mouse model of MCMV has been integral in the prediction of useful therapeutics for these clinical circumstances (reviewed in [59], with a discussion of the appropriate use for this model in reliably predicting human outcomes).

In order to model CMV-associated diseases occurring due to immunosuppression, such as retinitis or post-transplantation reactivation, the animal model needs to be manip- 
ulated to ensure similarity to human infection. The modification can be due to chemical administration (e.g., corticosteroid use), genetic modification of either the virus or the mouse strain used (e.g., MCMV-deleted m157 virus $(\Delta 157)$ allows C57BL/6 mice to be used without NK cell activation by the virus) or physiological treatment such as surgery. These modified models are listed in Table 2.

\subsection{Exacerbates the Effects of Other Clinical Diseases}

For some models, the addition of MCMV can exacerbate disease, reflecting human disease particularly in the intensive care unit setting. These are generally diseases with an immune modulation component. These models are listed in Table 3.

\subsection{Routes of Infection}

Many early CMV diseases were modeled using the intraperitoneal route of infection. The movement of a virus from the site of vaccination and the dissemination of a virus via peritoneal macrophages to visceral organs and, finally, to the salivary gland has been well described [60]. This route of inoculation does not correlate well with natural routes of infection, and other inoculation sites, such as the footpad, have also been used in some iterations of the MCMV disease model. Inoculation of a virus via the footpad (also referred to as intrafoot) is thought to model transmission by biting, and the infectious virus moves to the popliteal lymph node, infecting resident subcapsular sinus macrophages, although these cells do not allow lytic replication. Viremia and further organ infection may be due to a cell-free virus [61]. Recently, the intranasal route of inoculation (simulating transmission from mother to offspring via grooming) has been investigated more rigorously, and this has demonstrated that the visceral organs do not show the same level of viral replication as is seen with other routes of administration [62]. When investigated using a fluorophore-labeled virus, it was demonstrated that infection was via the olfactory neurons and disseminated by day 16 after inoculation to the salivary gland [63]. The MCMV/mouse model has recently been used to show temporal differences in virus dynamics and that there is interplay between different viral strains. Importantly, this work suggests that an increased number of virus strains present in one mouse is not indicative of more substantial pathological changes [64].

Table 2. Models for CMV disease, requiring significant laboratory manipulation.

\begin{tabular}{|c|c|c|c|c|c|c|c|}
\hline $\begin{array}{c}\text { Human } \\
\text { Condition }\end{array}$ & Lab Conditions & $\begin{array}{c}\mathrm{SGV}^{1 / \mathrm{TCV}^{2}} \\
\mathrm{PFU}^{3}\end{array}$ & $C^{4}$ & $\mathrm{G}^{5}$ & $P^{6}$ & Effect & Reference \\
\hline $\begin{array}{l}\text { Reactivation } \\
\text { after immuno- } \\
\text { suppression }\end{array}$ & $\begin{array}{l}\text { i.p. inoculation of } \\
\mathrm{C} 3 \mathrm{H} / \mathrm{St} \text { mice. }\end{array}$ & $\begin{array}{l}\text { SGV subcutaneous } \\
\text { infection with } \\
10^{3} \mathrm{PFU} \\
\text { Latency = } 8 \text { months }\end{array}$ & $x$ & & & $\begin{array}{c}\text { Immunosuppression } \\
\text { by rabbit } \\
\text { antilymphocyte } \\
\text { serum and } \\
\text { corticosteroid. }\end{array}$ & [65] \\
\hline Pneumonitis & $\begin{array}{c}\text { Intranasal } \\
\text { MCMV plus } \\
\text { cyclophosphamide } \\
24 \mathrm{~h} \text { after viral } \\
\text { inoculation in } \\
\text { BALB/c. }\end{array}$ & SGV, $10^{5} \mathrm{PFU}$ & $x$ & & & $\begin{array}{c}\text { Interstitial } \\
\text { pneumonitis. }\end{array}$ & $\begin{array}{c}{[66]} \\
\text { Reviewed in } \\
{[67]}\end{array}$ \\
\hline Atherogenesis & $\begin{array}{l}\text { MCMV inoculated } \\
\text { i.p. in APO-E-/- } \\
\text { mice (C57BL/ } 6 \\
\text { background). }\end{array}$ & $\begin{array}{c}\text { SGV } 10^{5} \text { PFU } \\
\text { Or } 3 \times 10^{4} \text { PFU TCV }\end{array}$ & & $\mathrm{x}$ & & $\begin{array}{c}\text { Larger } \\
\text { atherosclerotic } \\
\text { lesions in infected } \\
\text { mice, potentially } \\
\text { caused by } \\
\text { upregulation } \\
\text { of p38. }\end{array}$ & {$[68,69]$} \\
\hline
\end{tabular}


Table 2. Cont.

\begin{tabular}{|c|c|c|c|c|c|c|c|}
\hline $\begin{array}{l}\text { Human } \\
\text { Condition }\end{array}$ & Lab Conditions & $\begin{array}{c}\mathrm{SGV}^{1} / \mathrm{TCV}^{2} \\
\mathrm{PFU}^{3}\end{array}$ & $C^{4}$ & $\mathrm{G}^{5}$ & $P^{6}$ & Effect & Reference \\
\hline $\begin{array}{l}\text { Transplant- } \\
\text { arteriosclerosis }\end{array}$ & $\begin{array}{c}\text { Human peripheral } \\
\text { blood } \\
\text { leukocyte/Rag- } \\
2-/-\gamma c-/- \\
\text { mouse-xenograft- } \\
\text { model inoculated } \\
\text { with HCMV. }\end{array}$ & $\begin{array}{c}\text { Segments of } \\
\text { mammary artery } \\
\text { incubated in vivo } \\
\text { with } 10^{5} \text { PFU HCMV } \\
\text { before implantation }\end{array}$ & & $\mathrm{x}$ & $x$ & $\begin{array}{c}\text { Transplant } \\
\text { arteriosclerosis } \\
\text { was significantly } \\
\text { elevated and } \\
\text { increased ICAM-1, } \\
\text { PDGF-R-b and } \\
\text { macrophages. }\end{array}$ & {$[70]$} \\
\hline $\begin{array}{l}\text { Reactivation of } \\
\text { CMV infection } \\
\text { post organ } \\
\text { transplantation }\end{array}$ & $\begin{array}{l}\text { Immunosuppression } \\
\text { of BALB/c mice } \\
\text { receiving donor } \\
\text { kidney (C57BL/6 } \\
\text { allograft) leads to } \\
\text { dissemination of } \\
\text { reactivated MCMV. }\end{array}$ & $\begin{array}{c}\text { SGV } 10^{7} \text { PFU } \\
\text { MCMV- } \Delta \text { m157. } \\
\text { Mice used as donors } \\
\text { 4-8 months post i.p. } \\
\text { inoculation (latency) }\end{array}$ & $\mathrm{x}$ & & $\mathrm{x}$ & $\begin{array}{l}\text { Two-step process: } \\
\text { allograft ischemia } \\
\text { and reperfusion } \\
\text { injury (step 1). } \\
\text { Immunosuppression } \\
\text { mediated viral } \\
\text { dissemination } \\
\text { (step 2). }\end{array}$ & [71] \\
\hline $\begin{array}{l}\text { Sjogren's } \\
\text { syndrome }\end{array}$ & $\begin{array}{c}\text { 1. MCMV inoculated } \\
\text { i.p. in Fas-deficient } \\
\text { C57Bl/6- } \\
\text { lpr/lpr mice. } \\
\text { 2. MCMV inoculated } \\
\text { i.p. in tumor necrosis } \\
\text { factor-related } \\
\text { apoptosis-inducing } \\
\text { ligand deficient } \\
\text { BALB/c mice. }\end{array}$ & $\begin{array}{l}\text { SGV, } 10^{5} \text { PFU } \\
\text { SGV } 10^{4} \text { PFU }\end{array}$ & & $\begin{array}{l}x \\
x\end{array}$ & & $\begin{array}{l}\text { Salivary gland } \\
\text { inflammation and } \\
\text { autoantibody } \\
\text { production. } \\
\text { Autoantibody } \\
\text { production and } \\
\text { lymphocytic } \\
\text { aggregates. }\end{array}$ & [72] \\
\hline \multirow[t]{2}{*}{$\begin{array}{l}\text { Reactivation of } \\
\text { CMV infection } \\
\text { post } \\
\text { haemopoietic cell } \\
\text { transplantation }\end{array}$} & $\begin{array}{c}\text { 1. BALB/c mice } \\
\text { undergo sublethal } \\
\text { irradiation }(6 \mathrm{~Gy}), \\
\text { undergo syngeneic } \\
\text { haematopoietic stem } \\
\text { cell transplant } 6 \mathrm{~h} \\
\text { later, } 2 \mathrm{~h} \text { later } \\
\text { inoculated with } \\
\text { CMV via foot pad. }\end{array}$ & TCV $10^{5}$ PFU & & & \multirow[t]{2}{*}{$\mathrm{x}$} & $\begin{array}{c}\text { Pulmonary } \\
\text { infection control } \\
\text { depends on CD8 T } \\
\text { cell reconstitution. }\end{array}$ & [73] \\
\hline & $\begin{array}{l}\text { 2. CD8 T cell } \\
\text { immunotherapy. }\end{array}$ & & & & & $\begin{array}{l}\text { Controls CMV } \\
\text { associated im- } \\
\text { munopathology. }\end{array}$ & $\begin{array}{c}{[74]} \\
\text { Reviewed in } \\
\text { [59] }\end{array}$ \\
\hline \multirow[b]{2}{*}{$\begin{array}{l}\text { Graft versus } \\
\text { host disease }\end{array}$} & \multirow{2}{*}{$\begin{array}{l}\text { 1. Inoculated with } \\
\text { MCMV } 3 \text { days prior } \\
\text { to transplant. } \\
\text { A variety of } \\
\text { H-2 defined mice } \\
\text { inoculated i.v. } \\
\text { with spleen cells } \\
\text { (either MHC1 or } \\
\text { MHCII disparity). } \\
\text { 2. Strain specific } \\
\text { antibody therapy. } \\
\text { Latently inoculated } \\
\text { mice (i.p). }\end{array}$} & $1 \times \mathrm{LD}_{50} \mathrm{SGV}$ & & $x$ & & $\begin{array}{l}\text { Reduction of CTL } \\
\text { and } \\
\text { immunodeficiency } \\
\text { induced, } 10 \times \text { less } \\
\text { donor } \\
\text { cells required. }\end{array}$ & [75] \\
\hline & & $\begin{array}{c}10^{4}(\mathrm{~B} 6 \text { or B6D2F1) } \\
\text { or } 5 \times 10^{3} \mathrm{PFU} \\
(\mathrm{BALB} / \mathrm{c}) \mathrm{SGV}\end{array}$ & & $\mathrm{x}$ & & $\begin{array}{l}\text { Strain-specific } \\
\text { antibody therapy } \\
\text { protects from } \\
\text { MCMV } \\
\text { reactivation. }\end{array}$ & [76] \\
\hline
\end{tabular}


Table 2. Cont.

\begin{tabular}{|c|c|c|c|c|c|c|c|}
\hline $\begin{array}{l}\text { Human } \\
\text { Condition }\end{array}$ & Lab Conditions & $\begin{array}{c}\mathrm{SGV}^{1 / \mathrm{TCV}^{2}} \\
\mathrm{PFU}^{3}\end{array}$ & $C^{4}$ & $\mathrm{G}^{5}$ & $P^{6}$ & Effect & Reference \\
\hline $\begin{array}{l}\text { Transplant- } \\
\text { arteriosclerosis }\end{array}$ & $\begin{array}{c}\text { Human peripheral } \\
\text { blood } \\
\text { leukocyte/Rag- } \\
2-/-\gamma c-/- \\
\text { mouse-xenograft- } \\
\text { model inoculated } \\
\text { with HCMV. }\end{array}$ & $\begin{array}{c}\text { Segments of } \\
\text { mammary artery } \\
\text { incubated in vivo } \\
\text { with } 10^{5} \text { PFU HCMV } \\
\text { before implantation }\end{array}$ & & $\mathrm{x}$ & $x$ & $\begin{array}{c}\text { Transplant } \\
\text { arteriosclerosis } \\
\text { was significantly } \\
\text { elevated and } \\
\text { increased ICAM-1, } \\
\text { PDGF-R-b and } \\
\text { macrophages. }\end{array}$ & [70] \\
\hline \multirow[t]{2}{*}{ CMV retinitis } & $\begin{array}{l}\text { 1. Inoculation into } \\
\text { supraciliary space } \\
\text { (described in [77]) + } \\
\text { immunosuppression } \\
\text { of BALB/c mice via } \\
\text { methylprednisolone } \\
\text { every } 3 \text { days starting } \\
2 \text { days prior to } \\
\text { inoculation. }\end{array}$ & $\mathrm{SGV} 5 \times 10^{3} \mathrm{PFU}$ & $\mathrm{x}$ & & & $\begin{array}{l}\text { Retinitis abrogated } \\
\text { using i.v. siRNAs } \\
\text { directed against } \\
\text { MCMV immediate } \\
\text { early protein-3 } \\
\text { (IE-3). }\end{array}$ & {$[78,79]$} \\
\hline & $\begin{array}{l}\text { 2. Immunosuppres- } \\
\text { sion using } \\
\text { C57Bl/6J intraretinal } \\
\text { inoculation } \\
\text { PLUS MAIDs. }\end{array}$ & SGV $10^{4} \mathrm{PFU}$ & $\mathrm{x}$ & & & $\begin{array}{l}\text { (MAIDS- } \\
\text { retrovirus mixture } \\
\text { defined in [80]) } \\
\text { Severity of effect } \\
\text { may be due to } \\
\text { suppressor of } \\
\text { cytokine signaling } \\
\text { (SOCS) } 1 \text { and } 2 \text {. }\end{array}$ & [81] \\
\hline $\begin{array}{l}\text { Renal allograft } \\
\text { loss due to } \\
\text { MCMV } \\
\text { reactivation } \\
\text { (donor positive) }\end{array}$ & $\begin{array}{l}\text { Donor BALB/c } \\
\text { recipient } \\
\text { C57Bl/6 after renal } \\
\text { transplantation. }\end{array}$ & $\begin{array}{c}\text { TCV MCMV or } \\
\Delta \mathrm{m} 157, \text { Infection } \\
\text { with } 10^{4} \text { PFU } \\
(\Delta \mathrm{m} 157) \text { all donors. } \\
\text { Recipient either } 10^{4} \\
\text { PFU } \Delta \mathrm{m} 157 / \text { WT or } \\
10^{2} \Delta \mathrm{m} 157 .\end{array}$ & & $x$ & $x$ & $\begin{array}{l}\text { Th17 inhibition } \\
\text { reduced injury } \\
\text { to graft. }\end{array}$ & [82] \\
\hline $\begin{array}{l}\text { Brain infection in } \\
\text { immunosup- } \\
\text { pressed } \\
\text { patients }\end{array}$ & $\begin{array}{l}\text { Severe combined } \\
\text { immunodeficient } \\
\text { (SCID) mice } \\
\text { (BALB/c } \\
\text { background), } \\
\text { intracranial infection. } \\
\text { Virus expressing } \\
\text { green fluorescent } \\
\text { protein (GFP). }\end{array}$ & $\begin{array}{c}\mathrm{TCV}, 10^{6} \mathrm{PFU}(\mathrm{GFP}) \\
4.83 \times 10^{5} \mathrm{PFU} \\
\text { wildtype }\end{array}$ & & $x$ & $x$ & $\begin{array}{l}\text { Adoptive transfer } \\
\text { of MCMV-specific } \\
\text { CD4 T cells clears } \\
\text { CMV from the } \\
\text { brain. Treatment } \\
\text { prior to infection } \\
\text { prevents MCMV } \\
\text { replication. }\end{array}$ & [83] \\
\hline $\begin{array}{l}\text { Hemophagocytic } \\
\text { lymphohistiocy- } \\
\text { tosis }\end{array}$ & $\begin{array}{c}\text { IFN- } \gamma \text {-knockout } \\
(\mathrm{KO}) \text { mice on } \\
\text { BALB } / \mathrm{c} \text { background } \\
\text { or BALB } / \mathrm{c}\end{array}$ & $\mathrm{SGV}, 5 \times 10^{3} \mathrm{PFU}$ & & $x$ & & $\begin{array}{c}\text { Severity not } \\
\text { associated with } \\
\text { titer, associated } \\
\text { with inflammation. }\end{array}$ & [84] \\
\hline $\begin{array}{l}\text { Laboratory } \\
\text { diagnosis } \\
\text { of hepatitis }\end{array}$ & $\begin{array}{l}\text { i.v. inoculation of } \\
\text { C57BL/ } 6 \text { mice with } \\
\text { marker virus } \\
\text { (luciferase, mCherry, } \\
\text { SINFEKL) }\end{array}$ & $\mathrm{TCV}, 10^{6} \mathrm{PFU}$ & & $\mathrm{x}$ & & $\begin{array}{c}\text { Blood } \\
\text { biochemistry levels } \\
\text { given (allowing } \\
\text { diagnosis } \\
\text { of hepatitis). }\end{array}$ & [85] \\
\hline
\end{tabular}

\footnotetext{
${ }^{1}$ Salivary gland-derived virus. ${ }^{2}$ Tissue culture-derived virus. ${ }^{3}$ Plaque-forming units. ${ }^{4}$ Chemical modification e.g., chemotherapeutic.

${ }^{5}$ Genetic modification of mouse or virus. ${ }^{6}$ Physiological treatment (e.g., surgery).
} 
Table 3. Models demonstrating MCMV-associated effects on other diseases.

\begin{tabular}{|c|c|c|c|c|}
\hline Medical Condition & Lab Conditions & $\begin{array}{c}\mathrm{SGV}^{1 / \mathrm{TCV}^{2}} \\
\text { PFU }^{3}\end{array}$ & Effect & Reference \\
\hline $\begin{array}{l}\text { Ulcerative colitis in } \\
\text { CMV-inoculated } \\
\text { individuals }\end{array}$ & $\begin{array}{c}\text { T cell receptor } \\
\text { alpha }-/- \text { mice } \\
\text { (C57BL/6 background) } \\
\text { inoculated i.p. at } 7 \text { days of } \\
\text { age with MCMV or } \\
\text { MCMV-enhanced GFP }\end{array}$ & $\begin{array}{c}\mathrm{TCV}, 5 \times 10^{5} \mathrm{PFU} \text { of MCMV } \\
\text { for C57BL/ } 6 \text { mice and } 2 \times \\
10^{4} \text { PFU of MCMV-EGFP for } \\
\text { TCR-alpha- }--\end{array}$ & $\begin{array}{l}\text { Ulcerative colitis is } \\
\text { exacerbated in latently } \\
\text { infected mice }\end{array}$ & [86] \\
\hline Growth of glioblastoma & $\begin{array}{l}\text { Mice inoculated i.p. } \\
\text { day } 2 \text { of life (P2), tumor } \\
\text { injection week } 15\end{array}$ & TCV $10^{3}$ PFU MCMV- $\triangle \mathrm{m} 157$ & $\begin{array}{l}\text { Tumor growth and } \\
\text { reduction in survival }\end{array}$ & [87] \\
\hline $\begin{array}{l}\text { CMV reactivation after } \\
\text { physical damage }\end{array}$ & $\begin{array}{l}\text { Caecal ligation and } \\
\text { puncture in latently i.p. } \\
\text { inoculated BALB/c mice }\end{array}$ & $\mathrm{TCV}, 2 \times 10^{4} \mathrm{cgrmPFU}$ & $\begin{array}{l}\text { Plus } S \text {. aureus to induce } \\
\text { bacterial pneumonia }\end{array}$ & {$[88,89]$} \\
\hline $\begin{array}{l}\text { MCMV infection } \\
\text { after cholestasis }\end{array}$ & $\begin{array}{l}\text { C57BL/ } 8 \text { mice bile duct } \\
\text { ligated, inoculated i.p. } \\
\Delta \text { m157-MCMV-luciferase }\end{array}$ & $\begin{array}{l}\text { SGV / TCV not specified. } \\
2 \times 10^{5} \mathrm{PFU}\end{array}$ & $\begin{array}{l}\text { Impaired inflammatory } \\
\text { response, but no } \\
\text { increase in } \\
\text { liver pathology }\end{array}$ & [90] \\
\hline $\begin{array}{l}\text { Melanomas growth, } \\
\text { repeated injection } \\
\text { recapitulates transient } \\
\text { response }\end{array}$ & $\begin{array}{l}\text { Intra-tumoral inoculation } \\
\text { of MCMV or } \triangle \mathrm{gL} \text { MCMV } \\
\text { (spread deficient) impairs } \\
\text { melanoma growth in } \\
\text { BALB/c mice }\end{array}$ & $\begin{array}{l}\text { TCV (described in [91]), } \\
5 \times 10^{5} \mathrm{PFU}\end{array}$ & $\begin{array}{l}\text { Infection of } \\
\text { macrophages leads to } \\
\text { proinflammatory } \\
\text { M1 state }\end{array}$ & [92] \\
\hline $\begin{array}{l}\text { Idiopathic } \\
\text { pulmonary fibrosis }\end{array}$ & $\begin{array}{c}\text { Latent MCMV infection in } \\
\text { BALB/c mice } \\
\text { (i.p. }-4 \text { weeks prior), } \\
\text { intratracheal bleomycin }\end{array}$ & $\mathrm{SGV}, 10^{5} \mathrm{PFU}$ & $\begin{array}{l}\text { MCMV-exacerbated } \\
\text { fibrosis, activation of } \\
\text { TGF- } \beta 1\end{array}$ & [93] \\
\hline $\begin{array}{c}\text { Experimental } \\
\text { autoimmune } \\
\text { encephalomyelitis } \\
\text { (EAE) }\end{array}$ & $\begin{array}{c}\text { C57BL/6J and } \\
\text { CD80/86-/ }- \text { mice } \\
\text { inoculated with MCMV i.p. } \\
\text { and } 8 \text { days later, } \\
\text { EAE induced }\end{array}$ & $\mathrm{SGV}, 5 \times 10^{4} \mathrm{PFU}$ & $\begin{array}{c}\text { More severe disease } \\
\text { (e.g., enhanced } \\
\text { demyelination), } \\
\text { severity associated } \\
\text { with number of splenic } \\
\text { CD4 } 4^{+} \text {CD28 } 28^{\text {null }} \text { T cells }\end{array}$ & [94] \\
\hline $\begin{array}{l}\text { Use of bronchiolar } \\
\text { lavage (BAL) to detect } \\
\text { reactivation of CMV } \\
\text { in sepsis }\end{array}$ & $\begin{array}{l}\text { BALB/c mice inoculated } \\
\text { with MCMV, sepsis by } \\
\text { caecal ligation } \\
\text { and puncture }\end{array}$ & $\begin{array}{l}\text { SGV / TCV not specified; } \\
10^{2}, 10^{6}\end{array}$ & $\begin{array}{l}\text { qPCR of BAL cell } \\
\text { pellets similar to that of } \\
\text { lung tissue }\end{array}$ & [95] \\
\hline Acute colitis & C57BL/ 6 mice & $\mathrm{TCV}, 3 \times 10^{4} \mathrm{PFU}$ & $\begin{array}{l}\text { Acceleration of colitis } \\
\text { development, but no } \\
\text { difference in histology }\end{array}$ & [96] \\
\hline Allergic airway disease & $\begin{array}{l}\text { C57BL / } 6 \text { mice inoculated } \\
\text { intra tracheally }\end{array}$ & $\mathrm{TCV}, 10^{6} \mathrm{PFU}$ & $\begin{array}{l}\text { Exposed to ovalbumin, } \\
\text { CMV- } \\
\text { exacerbated disease }\end{array}$ & [97] \\
\hline
\end{tabular}

${ }^{1}$ Salivary gland-derived virus. ${ }^{2}$ Tissue culture-derived virus. ${ }^{3}$ Plaque-forming units.

\subsection{Humanized Mouse Models}

The manipulation of mice to allow humanized features allows infection with HCMV [98] and increases the repertoire of testing available for HCMV preventative strategies, as well as pre-clinical testing of treatments such as chemotherapeutic interventions. For example, humanized immune system mice have been investigated for future use in modeling vaccine efficacy [99]. Although this strategy provides additional information, the validity of the results needs to be carefully evaluated in every model, particularly with respect to the immune responses generated in the mouse. 


\subsection{Immunology and MCMV Studies}

This is a large topic and will not be reviewed extensively here, although many fundamental discoveries have been possible due to the robust nature of this murine model. Research using MCMV has allowed specific viral immune defense processes to be elucidated and for basic research investigating the activity and effector functions of immune cells to be undertaken. These studies have provided important insights into defense from lifelong HCMV infection, including the interesting phenomenon of memory inflation, where a disproportionate percentage of the CD8+ T cell response is devoted toward HCMV immunity [100]. Immune responses to MCMV have been recently reviewed [101].

\subsubsection{Innate Immune Responses}

Innate immune responses determine the severity of infection, and NK cells play an important early role in defense from MCMV infection. Research in this area (originally undertaken to describe the difference in $\mathrm{LD}_{50}$ between different mouse strains [102]) has demonstrated the presence of NK cell activating receptors and the antigen-specific inflation of NK cell populations [103], responsible for the increased resistance of C57BL/6 mice to MCMV infection compared with BALB/c mice [104]. Altered NK cell development and the development of long-lasting NK cell memory has been demonstrated using the mouse model (reviewed in [105]), altering the perception of NK cells as only contributing to innate immune processes. Recent evidence that infection via the intranasal route infects restricted cell types suggests that the route of infection needs to be carefully assessed in these models [106]. Cytokines produced as a result of MCMV infection are responsible for tissue damage, as well as suppression of pathology, and were discussed in detail in a recent review [107].

\subsubsection{Adaptive Immune Responses}

Strong humoral and cell-mediated immunity is induced after primary infection with MCMV, with CD8+ T cells being important for the control of viral clearance from many organs [108] and having recently been confirmed to inhibit MCMV-associated effects on hematopoiesis in bone marrow graft rejection [109]. The importance of CD4+ T cells in viral clearance is well established [108], and more recent reports have shown that CD4+ $\mathrm{T}$ cells produce granzyme B and may directly kill infected cells in vivo [110]. Antibody responses to viral infection were characterized in different mouse strains in early research, which showed that autoantibodies were produced as part of the response to primary infection [47] and were due to polyclonal B cell responses [111]. Administration of a passive antibody reduces MCMV organ titers but does not prevent infection [112]. However, recent data suggests that the administration of an antibody toward glycoprotein B, even where the antibody is unable to neutralize the virus, may provide protection from disease [113].

\subsection{Congenital Infection with Cytomegalovirus}

One of the aspects of HCMV infection that has repeatedly been attempted using various manipulations of the basic MCMV/mouse model is congenital infection. In humans, symptomatic CMV infection is present in $0.07 \%$ of births [114]. The most serious sequelae are associated with primary maternal infection during the first trimester of pregnancy, including still births [115] as well as disseminated CMV inclusion disease [116]. If the transmission occurs later in pregnancy, the risk of transmission is greater (around $40 \%$ and $70 \%$, respectively), but the risk of the most serious sequelae is diminished [117]. Infection outcomes have a spectrum of symptoms, ranging from pneumonitis, hepatitis and growth restriction to mental retardation, impairment in motor function and escalating sensorineural hearing loss (SNHL) or, alternatively, children can remain clinically normal [118]. Congenital CMV (cCMV) infection is diagnosed using a combination of maternal serology, ultrasonography and amniocentesis, and the severity of disease cannot always be predicted with accuracy [119]. Virtually as soon as MCMV was isolated, attempts were 
made to model congenital disease, mostly with frustrating outcomes [120]. Experimental manipulation of the mouse/MCMV model to simulate human cCMV disease is shown in Table 4. To date, the most successful model of congenital disease is the guinea pig model (discussed in [121]). However, the disease is generally acute, and there are limitations with reagent availability and the lack of inbred lines for experimentation. Guinea pigs also have a much longer gestation period (around 65 days, compared with 21 days for mice) and often have three or fewer pups.

Table 4. Mouse models of human congenital cytomegalovirus (cCMV) disease (chronological order).

\begin{tabular}{|c|c|c|c|c|c|}
\hline Inoculation Details & Mouse & $\begin{array}{c}\mathrm{SGV}^{1} / \mathrm{TCV}^{2} \\
\mathrm{PFU}^{3}\end{array}$ & Effect & Year & Reference \\
\hline $\begin{array}{l}\text { Inoculation of } \\
\text { pregnant mice } \\
\text { (approx.) Day } 8 \\
\text { Inoculation of fetal } \\
\text { and neonatal mice }\end{array}$ & Outbred Harvard & $\begin{array}{l}1000 \text { fifty-percent } \\
\text { tissue culture } \\
\text { doses (stock was } \\
\text { stored as SGV) }\end{array}$ & $\begin{array}{l}\text { Placental infection, but no } \\
\text { evidence of fetal infection } \\
\text { after maternal infection. } \\
\text { Fetal infection (often } \\
\text { lethal) shows that fetal } \\
\text { mice are susceptible. }\end{array}$ & 1969 & [122] \\
\hline $\begin{array}{c}\text { Pregnant mice } \\
\text { inoculated i.p. } \\
\text { or intramuscularly } \\
\text { on } \mathrm{E}_{8}\end{array}$ & $\begin{array}{c}\text { TO Swiss outbred and } \\
\text { BALB/c }\end{array}$ & $\begin{array}{l}\text { SGV } 1.1 \times 10^{7} \\
\text { (Infective Dose }{ }_{50} \text { ) } \\
\text { at various } \\
\text { concentrations }\end{array}$ & $\begin{array}{l}\text { i.p. administration } \\
\text { produced more fetal } \\
\text { wastage and smaller litter } \\
\text { sizes. Placental weights } \\
\text { not changed. Maternal } \\
\text { illness pronounced. }\end{array}$ & 1978 & [123] \\
\hline $\begin{array}{l}\text { MCMV injected into } \\
\text { endometrial lumina on } \\
\text { day of implantation }\end{array}$ & CF1 (Albino Swiss) & TCV, 100-200 PFU & $\begin{array}{l}\text { Reduced litter sizes, } \\
\text { malformed fetuses (neural } \\
\text { tube defects). }\end{array}$ & 1987 & [124] \\
\hline $\begin{array}{l}\text { Maternal i.p. } \\
\text { inoculation on Day } \\
8 \text { of pregnancy }\end{array}$ & $\begin{array}{c}\mathrm{BALB} / \mathrm{c} \\
\mathrm{BALB} / \mathrm{K}, \mathrm{CBA}\end{array}$ & $\begin{array}{c}\text { SGV } \\
3.57 \times 10^{3} \mathrm{PFU}\end{array}$ & $\begin{array}{l}\text { Dose dependent, effect } \\
\text { related to MHC. No fetal } \\
\text { infection. Some placental } \\
\text { infection. }\end{array}$ & 1991 & [125] \\
\hline $\begin{array}{l}\text { In utero inoculation of } \\
\text { fetuses, Day } 8\end{array}$ & $\mathrm{BALB} / \mathrm{c}$ and CBA & SGV, 11 PFU & $\begin{array}{l}\text { High resorption rate in } \\
\text { BALB/c. }\end{array}$ & 1991 & [125] \\
\hline $\begin{array}{l}\text { Microinjection of } \\
\text { fertilized ova, cultured } \\
\text { to blastocyst } \\
\text { and implanted }\end{array}$ & $\mathrm{F} 1 \mathrm{SJL} \times \mathrm{C} 57 \mathrm{BL} / 6 \mathrm{~J}$ & $\begin{array}{c}2 \text { pL MCMV DNA } \\
(2.5 \mu \mathrm{g} / \mathrm{mL})\end{array}$ & $\begin{array}{l}\text { Maldeveloped fetuses, } \\
\text { increased resorptions. }\end{array}$ & 1993 & {$[126,127]$} \\
\hline $\begin{array}{l}\text { Inoculation of } \\
\text { conceptus D8.5 }\end{array}$ & ICR mice & $\mathrm{TCV}, 10^{4} \mathrm{PFU}$ & $\begin{array}{l}\text { Microphthalmia and } \\
\text { cerebral atrophy, } \\
\text { potentially model of } \\
\text { subclinical cCMV. }\end{array}$ & 1995 & {$[126,127]$} \\
\hline $\begin{array}{l}\text { Intraplacental } \\
\text { inoculation of } 10 \mathrm{ng} \\
\text { TNF-alpha (D12.5), i.v. } \\
\text { inoculation of mother } \\
2 \text { h later }\end{array}$ & ICR mice & $\mathrm{TCV}, 10^{5} \mathrm{PFU}$ & $\begin{array}{l}\text { Some growth retardation } \\
\text { and microcephaly }(25 \%) \text {. }\end{array}$ & 2000 & [128] \\
\hline $\begin{array}{l}\text { Maternal inoculation } \\
\text { of SCID mice i.p. }\end{array}$ & SCID mice & $\begin{array}{l}\mathrm{SGV}, 10^{3} \mathrm{PFU} \\
\quad \text { (varied) }\end{array}$ & $\begin{array}{c}\text { Maximal placental } \\
\text { transmission with } \\
\text { maternal infection at } \\
\text { E4 (i.p.). }\end{array}$ & 2007 & [129] \\
\hline $\begin{array}{l}\text { MCMV inoculated i.p. } \\
\text { into newborn pups }\end{array}$ & $\mathrm{BALB} / \mathrm{c}$ & TCV, 500 PFU & $\begin{array}{l}\text { 1. Infection in brain. } \\
\text { 2.P3-P5 prednisolone } \\
\text { cochlear inflammation. }\end{array}$ & $\begin{array}{l}2008 \\
2019\end{array}$ & $\begin{array}{c}\text { [130], } \\
\text { reviewed } \\
\text { in [131] } \\
{[132]}\end{array}$ \\
\hline
\end{tabular}


Table 4. Cont.

\begin{tabular}{|c|c|c|c|c|c|}
\hline Inoculation Details & Mouse & $\begin{array}{c}\mathrm{SGV}^{1 / \mathrm{TCV}^{2}} \\
\mathrm{PFU}^{3}\end{array}$ & Effect & Year & Reference \\
\hline $\begin{array}{l}\text { i.p. inoculation of } \\
\text { neonatal mice } \\
\text { plus intracerebral } \\
\text { inoculation of } E \text {. } \\
\text { coli-derived } \\
\text { lipopolysaccharide }\end{array}$ & BALB/c mice & $\mathrm{TCV}, 10^{5}$ & $\begin{array}{l}\text { Labyrinthitis, significant } \\
\text { increase in mean sound } \\
\text { pressure level responses } \\
\text { due to disruption of the } \\
\text { blood labyrinth barrier. }\end{array}$ & 2008 & [133] \\
\hline $\begin{array}{c}\text { i.p. RM427+ } \\
\text { (recombinant virus } \\
\text { expressing LacZ from } \\
\text { ie2) mated 5-12 days } \\
\text { later, evaluated on } \\
\text { D17-18 of pregnancy }\end{array}$ & C57BL/ 6 & $\mathrm{TCV}, 10^{6}$ & $\begin{array}{l}\text { Increased vasodilation in } \\
\text { pregnancy implicating } \\
\text { CMV in } \\
\text { hypertensive disorders. }\end{array}$ & 2009 & [134] \\
\hline $\begin{array}{l}\text { Intracerebral } \\
\text { inoculation of } \\
\text { neonatal mice }\end{array}$ & $\mathrm{BALB} / \mathrm{c}$ & TCV, 17-1700 PFU & $\begin{array}{l}\text { Sensorineural hearing loss } \\
\text { with dose response. }\end{array}$ & 2015 & [135] \\
\hline $\begin{array}{c}\text { Acute group } \\
\text { inoculated i.p. } \\
\text { MCMV at } \\
\text { E7.5 pre-pregnancy, } \\
\text { inoculated i.p. mated } \\
\text { one month later, } \\
\text { PBS E12.5 }\end{array}$ & BALB/c mice & $\mathrm{SGV}, 5 \times 10^{3} \mathrm{PFU}$ & $\begin{array}{l}\text { Acute toll-like receptor } \\
2 \text { and } 4 \text { upregulation in } \\
\text { acute group. Increased } \\
\text { placental size in } \\
\text { pre-pregnancy group. }\end{array}$ & 2018 & [136] \\
\hline
\end{tabular}

${ }^{1}$ Salivary gland derived virus, ${ }^{2}$ Tissue Culture derived virus ${ }^{3}$ Plaque forming Units.

\subsubsection{Mouse Models of Congenital Infection}

Early studies of CCMV used relatively high titers of SGV and generally resulted in fetal loss (resorption) and growth restriction that was attributed to maternal illness or placental insufficiency $[122,125]$. It is important to note that the mice in these early studies were not likely to be specific pathogen free and undetected co-infections may have affected these data. Experimental maternal infection with MCMV was often associated with smaller placentae, and although placental infection was reported by some researchers, transmission to the fetus was rarely detected, and resorption of fetuses was common. This suggested that fundamental differences between the mouse and human placentae may be responsible.

\subsubsection{Comparative Anatomy of Mouse and Human Placentae}

There are many similarities between the placentae of humans and mice, with the most notable being that both are hemochorial (i.e., having a trophoblast surface that is in direct contact with maternal blood). The most obvious difference, and one that probably results in reduced fetal infection, is that mice have three trophoblast layers-one is mononuclear and two are syncytial-separating the maternal and fetal blood, compared with the single syncytiotrophoblast layer found in human placentae $[137,138]$. The three-cell layer has previously been theorized to act as a physical barrier to the transmission of MCMV [122]. However, the reported congenital infection of severe combined immunodeficient (SCID) mouse pups leading to intrauterine growth restriction and microcephaly suggested that this physical barrier may not be responsible for differences between mice and humans [129]. The use of TCV rather than SGV has allowed some more subtle infections to be modeled, particularly involving infection of the placenta without significant resorption of fetuses (Figure 1). Female mice were mated and inoculated i.p. with MCMV TCV stock, either K181 Perth, the origins of which have been recorded previously [52], or the Smith strain [139] on either $E_{0.5}$ (the day of fertilization) or $E_{4.5}$ (the day of implantation), and placentae were collected on $\mathrm{E}_{18.5}$. The placentae were weighed (UWA Animal Experimentation 
Ethics Committee approval 100/788). Figure 1 demonstrates that the placental size was significantly increased in mice infected on the day of fertilization compared with those infected on the day of implantation. Increased placental thickness is a hallmark of cCMV disease in humans [140].

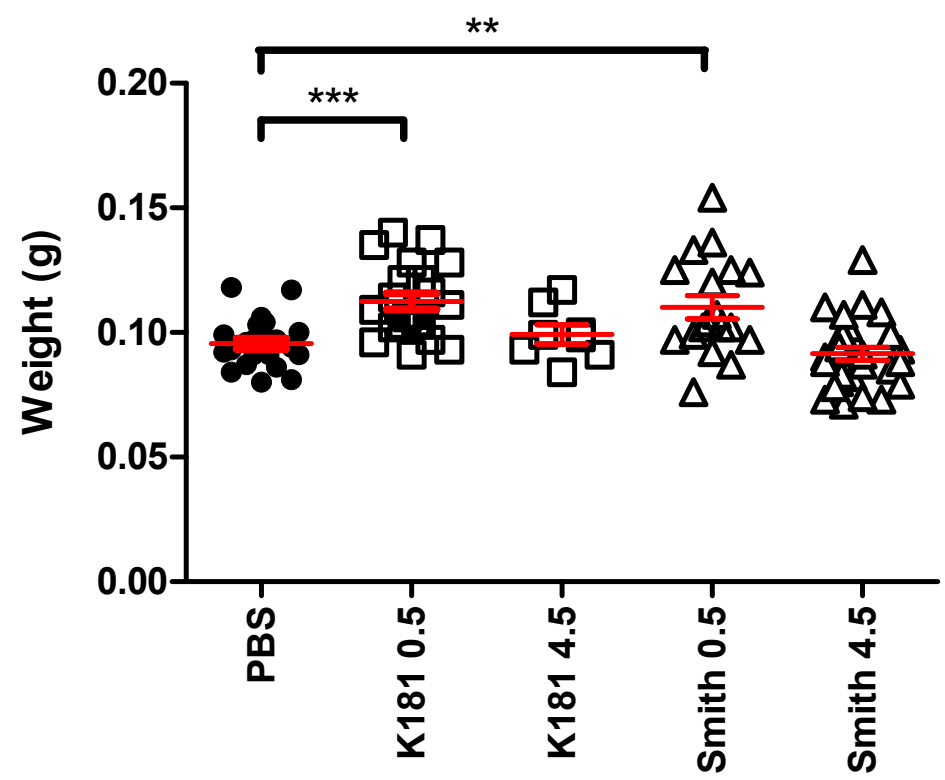

Figure 1. Effect of MCMV infection during pregnancy on placental weight (placental weights of E18.5 fetuses inoculated on day 0.5 or day 4.5 of pregnancy). Female BALB/c mice $(n=5)$ were infected with $2 \times 10^{4}$ PFU MCMV (K181 $1_{\text {Perth }}$ or Smith strain TCV) or the same volume of phosphate buffered saline (PBS) on the day of fertilization (E0.5) or on the day of blastocyst implantation (E4.5, viruses only) via the intraperitoneal route. Placentae were collected on E18.5 and weights were recorded. Mean $\pm \mathrm{SD}$ are shown in red. ${ }^{* *} p<0.01$. ${ }^{* * *} p<0.001$, ANOVA, Tukey's multiple comparison test.

\subsubsection{Mouse Brains Are Refractory to MCMV Infection}

Mouse embryonic stem cells have been reported to be refractory to MCMV infection, but neuronal stem progenitor cells are susceptible to infection, with brain infection occurring particularly at the cerebral subventricular zone [141]. Experiments using brain slice cultures have shown that the susceptibility of brain cells, particularly neural stem progenitor cells, to CMV infection may be associated with neurogenesis (reviewed in [142]). The susceptibility of newborn pups to brain infection after i.p. inoculation has been described, and the protection afforded by $\mathrm{CD}^{+} \mathrm{T}$ cells [143], CD8 ${ }^{+} \mathrm{T}$ cells [144], and antibodies [130] has been noted. This model has provided important information about sensorineural hearing loss [132]. Latent MCMV in brain tissue has been reactivated in brain slices in a culture from mice infected as newborn pups [145].

\section{Conclusion-Do Mice Lie?}

The MCMV/mouse model is a robust example of an animal model that should be used with a clear understanding of the differences between the human and mouse viruses, their adaptation to cultures and physiological differences between species, including differences in immune responses. MCMV has been very useful in modeling broad aspects of HCMV disease in many different situations, now greatly expanded with the use of recombinant viruses and genetically modified mouse strains. This has resulted in many different clinical conditions being accurately simulated and has allowed the opportunistic nature of HCMV, including its effect on the exacerbation of unrelated diseases, to be demonstrated. The only type of disease that is consistently difficult to replicate is congenital disease, due mostly to fetal resorption associated with acute maternal disease and potentially exacerbated by differences in placental structure and in the receptivity of the brain to MCMV 
replication. However, the use of TCV rather than SGV and the detection of viruses by means other than cultures, as well as careful evaluation of neonatal mouse inoculation, has provided some exciting alternative models with predictive capacity. Identifying the subtle differences in experimental procedures used by different researchers will improve experimental plans and aid in the appropriate interpretation of results.

Author Contributions: M.A.F. and M.L.L. both wrote the manuscript. M.A.F. and M.L.L. both carried out the experiment in Figure 1. M.L.L. designed the experiment and obtained competitive funding. All authors have read and agreed to the published version of the manuscript.

Funding: This Research was funded by a priming grant from the Raine Foundation and a University of Western Australia Research Award.

Acknowledgments: The authors would like to sincerely thank Jane Allan for her careful reading and inciteful comments on this manuscript.

Conflicts of Interest: The authors declare no conflict of interest.

$\begin{array}{ll}\text { Abbreviations } & \\ \text { MCMV } & \text { Murine cytomegalovirus } \\ \text { HCMV } & \text { Human cytomegalovirus } \\ \text { SGV } & \text { Salivary gland virus } \\ \text { TCV } & \text { Tissue culture virus } \\ \text { PFU } & \text { Plaque forming unit } \\ \text { i.p. } & \text { Intraperitoneal } \\ \text { i.v. } & \text { Intravenous } \\ \text { TNF } & \text { Tumor necrosis factor } \\ \text { MCP-1 } & \text { Monocyte Chemoattractant Protein-1 } \\ \text { ICAM-1 } & \text { Intercellular Adhesion Molecule 1 } \\ \text { TGF- } \beta & \text { Transforming Growth Factor-beta } \\ \text { CTL } & \text { Cytotoxic lymphocytes } \\ \text { PDGF } & \text { Platelet-derived growth factor } \\ \text { E0.5 } & \text { Day of fertilization }\end{array}$

\section{References}

1. Veazey, R.S. Animal models for microbicide safety and efficacy testing. Curr. Opin. HIV AIDS 2013, 8, 295-303. [CrossRef]

2. Blevins, S.M.; Bronze, M.S. Robert Koch and the 'golden age' of bacteriology. Int. J. Infect. Dis. 2010, 14, e744-e751. [CrossRef] [PubMed]

3. Byrd, A.L.; Segre, J.A. Adapting Koch's postulates. Science 2016, 351, 224-226. [CrossRef] [PubMed]

4. Prescott, J.; Feldmann, H.; Safronetz, D. Amending Koch's postulates for viral disease: When "growth in pure culture" leads to a loss of virulence. Antivir. Res. 2017, 137, 1-5. [CrossRef] [PubMed]

5. Fouchier, R.A.M.; Kuiken, T.; Schutten, M.; van Amerongen, G.; van Doornum, G.J.J.; van den Hoogen, B.G.; Peiris, M.; Lim, W.; Stöhr, K.; Osterhaus, A.D.M.E. Koch's postulates fulfilled for SARS virus. Nature 2003, 423, 240. [CrossRef]

6. Mullick, J.B.; Simmons, C.S.; Gaire, J. Animal Models to Study Emerging Technologies Against SARS-CoV-2. Cell. Mol. Bioeng. 2020, 13, 293-303. [CrossRef] [PubMed]

7. Song, J.; Wang, G.; Hoenerhoff, M.J.; Ruan, J.; Yang, D.; Zhang, J.; Yang, J.; Lester, P.A.; Sigler, R.; Bradley, M.; et al. Bacterial and Pneumocystis Infections in the Lungs of Gene-Knockout Rabbits with Severe Combined Immunodeficiency. Front. Immunol. 2018, 9, 429. [CrossRef]

8. Enkirch, T.; von Messling, V. Ferret models of viral pathogenesis. Virology 2015, 479-480, 259-270. [CrossRef]

9. St Claire, M.C.; Ragland, D.R.; Bollinger, L.; Jahrling, P.B. Animal Models of Ebolavirus Infection. Comp. Med. $2017,67,253-262$.

10. Ren, R.; Costantini, F.; Gorgacz, E.J.; Lee, J.J.; Racaniello, V.R. Transgenic mice expressing a human poliovirus receptor: A new model for poliomyelitis. Cell 1990, 63, 353-362. [CrossRef]

11. Parrish, C.R.; Holmes, E.C.; Morens, D.M.; Park, E.-C.; Burke, D.S.; Calisher, C.H.; Laughlin, C.A.; Saif, L.J.; Daszak, P. Crossspecies virus transmission and the emergence of new epidemic diseases. Microbiol. Mol. Biol. Rev. 2008, 72, 457-470. [CrossRef]

12. Shellam, G.R.; Redwood, A.J.; Smith, L.M.; Gorman, S. Cytomegalovirus and other herpesviruses. In The Mouse in Biomedical Research; Fox, J.G., Davisson, M.T., Quimby, F.W., Barthold, S.W., Newcomer, C.E., Smith, A.L., Eds.; Academic Press: San Diego, CA, USA, 2007; pp. 1-48.

13. McGeoch, D.J.; Cook, S.; Dolan, A.; Jamieson, F.E.; Telford, E.A.R. Molecular phylogeny and evolutionary timescale for the family of mammalian herpesviruses. J. Mol. Biol. 1995, 247, 443-458. [CrossRef] [PubMed] 
14. Sandford, G.R.; Brock, L.E.; Voigt, S.; Forester, C.M.; Burns, W.H. Rat Cytomegalovirus Major Immediate-Early Enhancer Switching Results in Altered Growth Characteristics. J. Virol. 2001, 75, 5076-5083. [CrossRef]

15. Michaels, M.G.; Jenkins, F.J.; St George, K.; Nalesnik, M.A.; Starzl, T.E.; Rinaldo, C.R. Detection of infectious baboon cytomegalovirus after baboon-to-human liver xenotransplantation. J. Virol. 2001, 75, 2825-2828. [CrossRef] [PubMed]

16. Denner, J. Xenotransplantation and porcine cytomegalovirus. Xenotransplantation 2015, 22, 329-335. [CrossRef] [PubMed]

17. Smith, C.B.; Wei, L.S.; Griffiths, M. Mouse cytomegalovirus is infectious for rats and alters lymphocyte subsets and spleen cell proliferation. Arch. Virol. 1986, 90, 313-323. [CrossRef]

18. Hudson, J.B.; Chantler, J.K.; Loh, L.; Misra, V.; Muller, M.T. Murine Cytomegalovirus-Model System for Study of Latent Herpes Infections. Can. J. Public Health 1978, 69, 72.

19. Moro, D.; Lloyd, M.L.; Smith, A.L.; Shellam, G.R.; Lawson, M.A. Murine viruses in an island population of introduced house mice and endemic short-tailed mice in Western Australia. J. Wildl. Dis. 1999, 35, 301-310. [CrossRef]

20. Smith, A.L.; Singleton, G.R.; Hansen, G.M.; Shellam, G. A serologic survey for viruses and Mycoplasma pulmonis among wild house mice (Mus domesticus) in southeastern Australia. J. Wildl. Dis. 1993, 29, 219-229. [CrossRef]

21. Rawlinson, W.D.; Farrell, H.E.; Barrell, B.G. Analysis of the complete DNA sequence of murine cytomegalovirus. J. Virol. 1996, 70, 8833-8849. [CrossRef]

22. Van Damme, E.; Van Loock, M. Functional annotation of human cytomegalovirus gene products: An update. Front. Microbiol. 2014, 5, 218. [CrossRef] [PubMed]

23. Wilkinson, G.W.G.; Davison, A.J.; Tomasec, P.; Fielding, C.A.; Aicheler, R.; Murrell, I.; Seirafian, S.; Wang, E.C.Y.; Weekes, M.; Lehner, P.J.; et al. Human cytomegalovirus: Taking the strain. Med. Microbiol. Immun. 2015, 204, 273-284. [CrossRef] [PubMed]

24. Cheng, T.P.; Valentine, M.C.; Gao, J.; Pingel, J.T.; Yokoyama, W.M. Stability of Murine Cytomegalovirus Genome after In Vitro and In Vivo Passage. J. Virol. 2010, 84, 2623-2628. [CrossRef] [PubMed]

25. Redwood, A.J.; Masters, L.L.; Chan, B.; Leary, S.; Forbes, C.; Jonjić, S.; Juranić Lisnić, V.; Lisnić, B.; Smith, L.M. Repair of an attenuated low passage murine cytomegalovirus bacterial artificial chromosome identifies a novel spliced gene essential for salivary gland tropism. J. Virol. 2020, 94. [CrossRef]

26. Brizić, I.; Lisnić, B.; Brune, W.; Hengel, H.; Jonjić, S. Cytomegalovirus Infection: Mouse Model. Curr. Protoc. Immunol. 2018, 122, e51. [CrossRef]

27. Osborn, J.E.; Walker, D.L. Virulence and Attenuation of Murine Cytomegalovirus. Infect. Immun. 1971, 3, 228-236. [CrossRef]

28. Mims, C.A.; Gould, J. Infection of salivary glands, kidneys, adrenals, ovaries and epithelia by murine cytomegalovirus. J. Med. Microbiol. 1978, 12, 113-122. [CrossRef]

29. Allan, J.E.; Shellam, G.R. Genetic control of murine cytomegalovirus infection: Virus titres in resistant and susceptible strains of mice. Arch. Virol. 1984, 81, 139-150. [CrossRef]

30. Grundy, J.E.; Mackenzie, J.S.; Stanley, N.F. Influence of H-2 and non-H-2 genes on resistance to murine cytomegalovirus infection. Infect. Immun. 1981, 32, 277-286. [CrossRef]

31. Hudson, J.B.; Misra, V.; Mosmann, T.R. Properties of the multicapsid virions of murine cytomegalovirus. Virology 1976, 72, 224-234. [CrossRef]

32. Pollock, J.L.; Virgin, H.W. Latency, without persistence, of murine cytomegalovirus in the spleen and kidney. J. Virol. 1995, 69, 1762-1768. [CrossRef] [PubMed]

33. Brune, W.; Hengel, H.; Koszinowski, U.H. A Mouse Model for Cytomegalovirus Infection. Curr. Protoc. Immunol. 2001, 43, 19.7.1-19.7.13. [CrossRef] [PubMed]

34. Roback, J.D.; Su, L.; Newman, J.L.; Saakadze, N.; Lezhava, L.J.; Hillyer, C.D. Transfusion-transmitted cytomegalovirus (CMV) infections in a murine model: Characterization of CMV-infected donor mice. Transfusion 2006, 46, 889-895. [CrossRef] [PubMed]

35. Reddehase, M.J.; Balthesen, M.; Rapp, M.; Jonjic, S.; Pavic, I.; Koszinowski, U.H. The conditions of primary infection define the load of latent viral genome in organs and the risk of recurrent cytomegalovirus disease. J. Exp. Med. 1994, 179, 185-193. [CrossRef] [PubMed]

36. Gonczol, E.; Danczig, E.; Boldogh, I.; Toth, T.; Vaczi, L. In vivo model for the acute, latent and reactivated phases of cytomegalovirus infection. Acta Microbiol. Hung. 1985, 32, 39-47. [PubMed]

37. Jordan, M.C. Interstitial pneumonia and subclinical infection after intranasal inoculation of murine cytomegalivirus. Infect. Immun. 1978, 21, 275-280. [CrossRef] [PubMed]

38. Fitzgerald, N.A.; Papadimitriou, J.M.; Shellam, G.R. Cytomegalovirus-induced pneumonitis and myocarditis in newborn mice A model for perinatal human cytomegalovirus infection. Arch. Virol. 1990, 115, 75-88. [CrossRef]

39. Hayashi, K.; Kurihara, I.; Uchida, Y. Studies of Ocular Murine Cytomegalovirus Infection. Investig. Ophthalmol. Vis. Sci. 1985, $26,486-493$.

40. Voigt, V.; Andoniou, C.E.; Schuster, I.S.; Oszmiana, A.; Ong, M.L.; Fleming, P.; Forrester, J.V.; Degli-Esposti, M.A. Cytomegalovirus establishes a latent reservoir and triggers long-lasting inflammation in the eye. PLoS Pathog. 2018, 14, e1007040. [CrossRef]

41. Wu, C.A.; Paveglio, S.A.; Lingenheld, E.G.; Zhu, L.; Lefrançois, L.; Puddington, L. Transmission of murine cytomegalovirus in breast milk: A model of natural infection in neonates. J. Virol. 2011, 85, 5115-5124. [CrossRef]

42. Cheng, J.L.; Ke, Q.G.; Jin, Z.; Kocher, O.; Morgan, J.P.; Zhang, J.L.; Crumpacker, C.S. Cytomegalovirus Infection Causes an Increase of Arterial Blood Pressure. PLoS Pathog. 2009, 5, e1000427. [CrossRef] [PubMed] 
43. Lenzo, J.C.; Fairweather, D.; Cull, V.; Shellam, G.R.; James Lawson, C.M. Characterisation of murine cytomegalovirus myocarditis: Cellular infiltration of the heart and virus persistence. J. Mol. Cell. Cardiol. 2002, 34, 629-640. [CrossRef] [PubMed]

44. Mutter, W.; Reddehase, M.J.; Busch, F.W.; Buhring, H.J.; Koszinowski, U.H. Failure in generating hemopoietic stem cells is the primary cause of death from cytomegalovirus disease in the immunocompromised host. J. Exp. Med. 1988, 167, 1645-1658. [CrossRef]

45. Young, J.A.; Cheung, K.S.; Lang, D.J. Infection and fertilization of mice after artificial insemination with a mixture of sperm and murine cytomegalovirus. J. Infect. Dis. 1977, 135, 837-840. [CrossRef]

46. Chalmer, J.E.; Mackenzie, J.S.; Stanley, N.F. Resistance to murine cytomegalovirus linked to the major histocompatibility complex of the mouse. J. Gen. Virol. 1977, 37, 107-114. [CrossRef]

47. Bartholomaeus, W.N.; O’Donoghue, H.; Foti, D.; Lawson, C.M.; Shellam, G.R.; Reed, W.D. Multiple autoantibodies following cytomegalovirus infection: Virus distribution and specificity of autoantibodies. Immunology 1988, 64, 397-405.

48. Lawson, C.M.; O'Donoghue, H.L.; Reed, W.D. Mouse cytomegalovirus infection induces antibodies which cross-react with virus and cardiac myosin: A model for the study of molecular mimicry in the pathogenesis of viral myocarditis. Immunology 1992, 75, 513-519.

49. Rodriguez, M.; Sabastian, P.; Clark, P.; Brown, M.G. Cmv1-Independent Antiviral Role of NK Cells Revealed in Murine Cytomegalovirus-Infected New Zealand White Mice. J. Immunol. 2004, 173, 6312-6318. [CrossRef]

50. Scalzo, A.A.; Fitzgerald, N.A.; Wallace, C.R.; Gibbons, A.E.; Smart, Y.C.; Burton, R.C.; Shellam, G.R. The effect of the Cmv1 resistance gene, which is linked to the natural killer cell gene complex, is mediated by natural killer cells. J. Immunol. 1992, $149,581-589$.

51. Lloyd, M.L.; Nikolovski, S.; Lawson, M.A.; Shellam, G.R. Innate antiviral resistance influences the efficacy of a recombinant murine cytomegalovirus immunocontraceptive vaccine. Vaccine 2007, 25, 679-690. [CrossRef]

52. Booth, T.W.; Scalzo, A.A.; Carrello, C.; Lyons, P.A.; Farrell, H.E.; Singleton, G.R.; Shellam, G.R. Molecular and biological characterization of new strains of murine cytomegalovirus isolated from wild mice. Arch. Virol. 1993, 132, 209-220. [CrossRef] [PubMed]

53. Nikolovski, S.; Lloyd, M.L.; Harvey, N.; Hardy, C.M.; Shellam, G.R.; Redwood, A.J. Overcoming innate host resistance to vaccination: Employing a genetically distinct strain of murine cytomegalovirus avoids vector-mediated resistance to virally vectored immunocontraception. Vaccine 2009, 27, 5226-5232. [CrossRef]

54. Zuhair, M.; Smit, G.S.A.; Wallis, G.; Jabbar, F.; Smith, C.; Devleesschauwer, B.; Griffiths, P. Estimation of the worldwide seroprevalence of cytomegalovirus: A systematic review and meta-analysis. Rev. Med. Virol. 2019, 29, e2034. [CrossRef] [PubMed]

55. Razonable, R.R.; Humar, A. Cytomegalovirus in solid organ transplant recipients-Guidelines of the American Society of Transplantation Infectious Diseases Community of Practice. Clin. Transplant. 2019, 33, e13512. [CrossRef] [PubMed]

56. Limaye, A.P.; Green, M.L.; Edmison, B.C.; Stevens-Ayers, T.; Chatterton-Kirchmeier, S.; Geballe, A.P.; Singh, N.; Boeckh, M. Prospective Assessment of Cytomegalovirus Immunity in High-Risk Donor-Seropositive/Recipient-Seronegative Liver Transplant Recipients Receiving Either Preemptive Therapy or Antiviral Prophylaxis. J. Infect. Dis. 2019, 220, 752-760. [CrossRef] [PubMed]

57. Hwang, S.D.; Lee, J.H.; Lee, S.W.; Kim, J.K.; Kim, M.J.; Song, J.H. Effect of Low-Dose Vs Standard-Dose Valganciclovir in the Prevention of Cytomegalovirus Disease in Kidney Transplantation Recipients: A Systemic Review and Meta-Analysis. Transplant. Proc. 2018, 50, 2473-2478. [CrossRef] [PubMed]

58. El Haddad, L.; Ghantoji, S.S.; Park, A.K.; Batista, M.V.; Schelfhout, J.; Hachem, J.; Lobo, Y.; Jiang, Y.; Rondon, G.; Champlin, R.; et al. Clinical and economic burden of pre-emptive therapy of cytomegalovirus infection in hospitalized allogeneic hematopoietic cell transplant recipients. J. Med. Virol. 2020, 92, 86-95. [CrossRef]

59. Reddehase, M.J.; Lemmermann, N.A.W. Mouse Model of Cytomegalovirus Disease and Immunotherapy in the Immunocompromised Host: Predictions for Medical Translation that Survived the "Test of Time". Viruses 2018, 10, 693. [CrossRef]

60. Hsu, K.M.; Pratt, J.R.; Akers, W.J.; Achilefu, S.I.; Yokoyama, W.M. Murine cytomegalovirus displays selective infection of cells within hours after systemic administration. J. Gen. Virol. 2009, 90, 33-43. [CrossRef]

61. Farrell, H.E.; Davis-Poynter, N.; Bruce, K.; Lawler, C.; Dolken, L.; Mach, M.; Stevenson, P.G. Lymph Node Macrophages Restrict Murine Cytomegalovirus Dissemination. J. Virol. 2015, 89, 7147-7158. [CrossRef]

62. Oduro, J.D.; Redeker, A.; Lemmermann, N.A.W.; Ebermann, L.; Marandu, T.F.; Dekhtiarenko, I.; Holzki, J.K.; Busch, D.H.; Arens, R.; Čičin-Šain, L. Murine cytomegalovirus (CMV) infection via the intranasal route offers a robust model of immunity upon mucosal CMV infection. J. Gen. Virol. 2016, 97, 185-195. [CrossRef] [PubMed]

63. Farrell, H.E.; Lawler, C.; Tan, C.S.; MacDonald, K.; Bruce, K.; Mach, M.; Davis-Poynter, N.; Stevenson, P.G. Murine Cytomegalovirus Exploits Olfaction To Enter New Hosts. MBio 2016, 7, e00251-16. [CrossRef]

64. McWhorter, A.R.; Smith, L.M.; Masters, L.L.; Chan, B.; Shellam, G.R.; Redwood, A.J. Natural Killer Cell Dependent Within-Host Competition Arises during Multiple MCMV Infection: Consequences for Viral Transmission and Evolution. PLoS Pathog. 2013, 9, e1003111. [CrossRef] [PubMed]

65. Jordan, M.C.; Shanley, J.D.; Stevens, J.G. Immunosuppression reactivates and disseminates latent murine cytomegalovirus. J. Gen. Virol. 1977, 37, 419-423. [CrossRef] [PubMed]

66. Shanley, J.D.; Pesanti, E.L. The relation of viral replication to interstitial pneumonitis in murine cytomegalovirus lung infection. J. Infect. Dis. 1985, 151, 454-458. [CrossRef] [PubMed] 
67. Fonseca Brito, L.; Brune, W.; Stahl, F.R. Cytomegalovirus (CMV) Pneumonitis: Cell Tropism, Inflammation, and Immunity. Int. J. Mol. Sci. 2019, 20, 3865. [CrossRef] [PubMed]

68. Tang-Feldman, Y.J.; Lochhead, S.R.; Lochhead, G.R.; Yu, C.; George, M.; Villablanca, A.C.; Pomeroy, C. Murine cytomegalovirus (MCMV) infection upregulates P38 MAP kinase in aortas of Apo E KO mice: A molecular mechanism for MCMV-induced acceleration of atherosclerosis. J. Cardiovasc. Transl. Res. 2013, 6, 54-64. [CrossRef]

69. Hsich, E.; Zhou, Y.F.; Paigen, B.; Johnson, T.M.; Burnett, M.S.; Epstein, S.E. Cytomegalovirus infection increases development of atherosclerosis in Apolipoprotein-E knockout mice. Atherosclerosis 2001, 156, 23-28. [CrossRef]

70. Abele-Ohl, S.; Leis, M.; Wollin, M.; Mahmoudian, S.; Hoffmann, J.; Muller, R.; Heim, C.; Spriewald, B.M.; Weyand, M.; Stamminger, T.; et al. Human Cytomegalovirus Infection Leads to Elevated Levels of Transplant Arteriosclerosis in a Humanized Mouse Aortic Xenograft Model. Am. J. Transplant. 2012, 12, 1720-1729. [CrossRef]

71. Zhang, Z.; Qiu, L.; Yan, S.; Wang, J.J.; Thomas, P.M.; Kandpal, M.; Zhao, L.; Iovane, A.; Liu, X.F.; Thorp, E.B.; et al. A clinically relevant murine model unmasks a "two-hit" mechanism for reactivation and dissemination of cytomegalovirus after kidney transplant. Am. J. Transplant. 2019, 19, 2421-2433. [CrossRef]

72. Fleck, M.; Kern, E.R.; Zhou, T.; Lang, B.; Mountz, J.D. Murine cytomegalovirus induces a Sjögren's syndrome-like disease in C57Bl/6-lpr/lpr mice. Arthritis Rheum. 1998, 41, 2175-2184. [CrossRef]

73. Podlech, J.; Holtappels, R.; Pahl-Seibert, M.F.; Steffens, H.P.; Reddehase, M.J. Murine model of interstitial cytomegalovirus pneumonia in syngeneic bone marrow transplantation: Persistence of protective pulmonary CD8-T-cell infiltrates after clearance of acute infection. J. Virol. 2000, 74, 7496-7507. [CrossRef] [PubMed]

74. Holtappels, R.; Böhm, V.; Podlech, J.; Reddehase, M.J. CD8 T-cell-based immunotherapy of cytomegalovirus infection: “proof of concept" provided by the murine model. Med. Microbiol. Immun. 2008, 197, 125-134. [CrossRef] [PubMed]

75. Via, C.S.; Shanley, J.D.; Shearer, G.M. Synergistic effect of murine cytomegalovirus on the induction of acute graft-vs-host disease involving MHC class I differences only. Analysis of in vitro T cell function. J. Immunol. 1990, 145, 3283-3289. [PubMed]

76. Martins, J.P.; Andoniou, C.E.; Fleming, P.; Kuns, R.D.; Schuster, I.S.; Voigt, V.; Daly, S.; Varelias, A.; Tey, S.K.; Degli-Esposti, M.A.; et al. Strain-specific antibody therapy prevents cytomegalovirus reactivation after transplantation. Science 2019, 363, $288-293$. [CrossRef]

77. Zhang, M.; Atherton, S.S. Apoptosis in the retina during MCMV retinitis in immuno suppressed BALB/c mice. J. Clin. Virol. 2002, 25, S137-S147. [CrossRef]

78. Mo, J.; Atherton, S.S.; Wang, L.; Liu, S. Autophagy protects against retinal cell death in mouse model of cytomegalovirus retinitis. BMC Ophthalmol. 2019, 19, 146. [CrossRef]

79. Marshall, B.; Mo, J.; Covar, J.; Atherton, S.S.; Zhang, M. Decrease of murine cytomegalovirus-induced retinitis by intravenous delivery of immediate early protein-3-specific siRNA. Investig. Ophthalmol. Vis. Sci. 2014, 55, 4151-4157. [CrossRef]

80. Dix, R.D.; Cray, C.; Cousins, S.W. Mice immunosuppressed by murine retrovirus infection (MAIDS) are susceptible to cytomegalovirus retinitis. Curr. Eye Res. 1994, 13, 587-595. [CrossRef]

81. Alston, C.I.; Dix, R.D. Reduced frequency of murine cytomegalovirus retinitis in C57BL/6 mice correlates with low levels of suppressor of cytokine signaling (SOCS) 1 and SOCS3 expression within the eye during corticosteroid-induced immunosuppression. Cytokine 2017, 97, 38-41. [CrossRef]

82. Li, M.; Boddeda, S.R.; Chen, B.; Zeng, Q.; Schoeb, T.R.; Velazquez, V.M.; Shimamura, M. NK cell and Th17 responses are differentially induced in murine cytomegalovirus infected renal allografts and vary according to recipient virus dose and strain. Am. J. Transplant. 2018, 18, 2647-2662. [CrossRef] [PubMed]

83. Reuter, J.D.; Wilson, J.H.; Idoko, K.E.; van den Pol, A.N. CD4(+) T-cell reconstitution reduces cytomegalovirus in the immunocompromised brain. J. Virol. 2005, 79, 9527-9539. [CrossRef] [PubMed]

84. Brisse, E.; Imbrechts, M.; Mitera, T.; Vandenhaute, J.; Wouters, C.H.; Snoeck, R.; Andrei, G.; Matthys, P. Lytic viral replication and immunopathology in a cytomegalovirus-induced mouse model of secondary hemophagocytic lymphohistiocytosis. Virol. J. 2017, 14, 240. [CrossRef] [PubMed]

85. Stahl, F.R.; Jung, R.; Jazbutyte, V.; Ostermann, E.; Tödter, S.; Brixel, R.; Kemmer, A.; Halle, S.; Rose-John, S.; Messerle, M.; et al. Laboratory diagnostics of murine blood for detection of mouse cytomegalovirus (MCMV)-induced hepatitis. Sci. Rep. 2018, 8, 14823. [CrossRef]

86. Matsumura, K.; Nakase, H.; Kosugi, I.; Honzawa, Y.; Yoshino, T.; Matsuura, M.; Kawasaki, H.; Arai, Y.; Iwashita, T.; Nagasawa, T.; et al. Establishment of a Novel Mouse Model of Ulcerative Colitis with Concomitant Cytomegalovirus Infection: In Vivo Identification of Cytomegalovirus Persistent Infected Cells. Inflamm. Bowel Dis. 2013, 19, 1951-1963. [CrossRef]

87. Krenzlin, H.; Behera, P.; Lorenz, V.; Passaro, C.; Zdioruk, M.; Nowicki, M.O.; Grauwet, K.; Zhang, H.; Skubal, M.; Ito, H.; et al. Cytomegalovirus promotes murine glioblastoma growth via pericyte recruitment and angiogenesis. J. Clin. Investig. 2019, 129, 1671-1683. [CrossRef]

88. Cook, C.H.; Zhang, Y.; McGuinness, B.J.; Lahm, M.C.; Sedmak, D.D.; Ferguson, R.M. Intra-abdominal bacterial infection reactivates latent pulmonary cytomegalovirus in immunocompetent mice. J. Infect. Dis. 2002, 185, 1395-1400. [CrossRef]

89. Hraiech, S.; Bordes, J.; Mège, J.L.; de Lamballerie, X.; Charrel, R.; Bechah, Y.; Pastorino, B.; Guervilly, C.; Forel, J.M.; Adda, M.; et al. Cytomegalovirus reactivation enhances the virulence of Staphylococcus aureus pneumonia in a mouse model. Clin. Microbiol. Infect. 2017, 23, 38-45. [CrossRef] 
90. Rattay, S.; Graf, D.; Kislat, A.; Homey, B.; Herebian, D.; Häussinger, D.; Hengel, H.; Zimmermann, A.; Schupp, A.K. Anti-inflammatory consequences of bile acid accumulation in virus-infected bile duct ligated mice. PLoS ONE 2018, 13, e0199863. [CrossRef]

91. Zurbach, K.A.; Moghbeli, T.; Snyder, C.M. Resolving the titer of murine cytomegalovirus by plaque assay using the M2-10B4 cell line and a low viscosity overlay. Virol. J. 2014, 11, 71. [CrossRef]

92. Wilski, N.A.; Del Casale, C.; Purwin, T.J.; Aplin, A.E.; Snyder, C.M. Murine Cytomegalovirus Infection of Melanoma Lesions Delays Tumor Growth by Recruiting and Repolarizing Monocytic Phagocytes in the Tumor. J. Virol. 2019, 93, e00533-19. [CrossRef]

93. Li, Y.; Gao, J.; Wang, G.; Fei, G. Latent cytomegalovirus infection exacerbates experimental pulmonary fibrosis by activating TGF- $\beta 1$. Mol. Med. Rep. 2016, 14, 1297-1301. [CrossRef]

94. Vanheusden, M.; Broux, B.; Welten, S.P.M.; Peeters, L.M.; Panagioti, E.; Van Wijmeersch, B.; Somers, V.; Stinissen, P.; Arens, R.; Hellings, N. Cytomegalovirus infection exacerbates autoimmune mediated neuroinflammation. Sci. Rep. 2017, 7, 663. [CrossRef] [PubMed]

95. Mansfield, S.; Dwivedi, V.; Byrd, S.; Trgovcich, J.; Griessl, M.; Gutknecht, M.; Cook, C.H. Broncholaveolar lavage to detect cytomegalovirus infection, latency, and reactivation in immune competent hosts. J. Med. Virol. 2016, 88, 1408-1416. [CrossRef] [PubMed]

96. Brunson, J.L.; Becker, F.; Stokes, K.Y. The impact of primary and persistent cytomegalovirus infection on the progression of acute colitis in a murine model. Pathophysiology 2015, 22, 31-37. [CrossRef] [PubMed]

97. Reuter, S.; Lemmermann, N.A.W.; Maxeiner, J.; Podlech, J.; Beckert, H.; Freitag, K.; Teschner, D.; Ries, F.; Taube, C.; Buhl, R.; et al. Coincident airway exposure to low-potency allergen and cytomegalovirus sensitizes for allergic airway disease by viral activation of migratory dendritic cells. PLoS Pathog. 2019, 15, e1007595. [CrossRef]

98. Crawford, L.B.; Streblow, D.N.; Hakki, M.; Nelson, J.A.; Caposio, P. Humanized mouse models of human cytomegalovirus infection. Curr. Opin. Virol. 2015, 13, 86-92. [CrossRef]

99. Koenig, J.; Theobald, S.J.; Stripecke, R. Modeling Human Cytomegalovirus in Humanized Mice for Vaccine Testing. Vaccines (Basel) 2020, 8, 89. [CrossRef]

100. Gabel, M.; Baumann, N.S.; Oxenius, A.; Graw, F. Investigating the Dynamics of MCMV-Specific CD8(+) T Cell Responses in Individual Hosts. Front. Immunol. 2019, 10, 1358. [CrossRef]

101. Berry, R.; Watson, G.M.; Jonjic, S.; Degli-Esposti, M.A.; Rossjohn, J. Modulation of innate and adaptive immunity by cytomegaloviruses. Nat. Rev. Immunol. 2020, 20, 113-127. [CrossRef]

102. Bancroft, G.J.; Shellam, G.R.; Chalmer, J.E. Genetic influences on the augmentation of natural killer (NK) cells during murine cytomegalovirus infection: Correlation with patterns of resistance. J. Immunol. 1981, 126, 988-994. [PubMed]

103. Nabekura, T.; Lanier, L.L. Tracking the fate of antigen-specific versus cytokine-activated natural killer cells after cytomegalovirus infection. J. Exp. Med. 2016, 213, 2745-2758. [CrossRef] [PubMed]

104. Scalzo, A.A.; Wheat, R.; Dubbelde, C.; Stone, L.; Clark, P.; Du, Y.; Dong, N.; Stoll, J.; Yokoyama, W.M.; Brown, M.G. Molecular genetic characterization of the distal NKC recombination hotspot and putative murine CMV resistance control locus. Immunogenetics 2003, 55, 370-378. [CrossRef] [PubMed]

105. Goodier, M.R.; Jonjić, S.; Riley, E.M.; Juranić Lisnić, V. CMV and natural killer cells: Shaping the response to vaccination. Eur. J. Immunol. 2018, 48, 50-65. [CrossRef]

106. Farrell, H.E.; Bruce, K.; Lawler, C.; Stevenson, P.G. Murine Cytomegalovirus Spread Depends on the Infected Myeloid Cell Type. J. Virol. 2019, 93, e00540-19. [CrossRef] [PubMed]

107. Clement, M.; Humphreys, I.R. Cytokine-Mediated Induction and Regulation of Tissue Damage During Cytomegalovirus Infection. Front. Immunol. 2019, 10, 78. [CrossRef]

108. Jonjic, S.; Mutter, W.; Weiland, F.; Reddehase, M.J.; Koszinowski, U.H. Site-restricted persistent cytomegalovirus infection after selective long-term depletion of CD4+ T lymphocytes. J. Exp. Med. 1989, 169, 1199-1212. [CrossRef]

109. Renzaho, A.; Podlech, J.; Kühnapfel, B.; Blaum, F.; Reddehase, M.J.; Lemmermann, N.A.W. Cytomegalovirus-Associated Inhibition of Hematopoiesis Is Preventable by Cytoimmunotherapy With Antiviral CD8 T Cells. Front. Cell. Infect. Microbiol. 2020, 10, 138. [CrossRef]

110. Verma, S.; Weiskopf, D.; Gupta, A.; McDonald, B.; Peters, B.; Sette, A.; Benedict, C.A. Cytomegalovirus-Specific CD4 T Cells Are Cytolytic and Mediate Vaccine Protection. J. Virol. 2016, 90, 650-658. [CrossRef]

111. Price, P.; Olver, S.D.; Gibbons, A.E.; Shellam, G.R. B-cell activation following murine cytomegalovirus infection: Implications for autoimmunity. Immunology 1993, 78, 14-21.

112. Lawson, C.M.; Grundy, J.E.; Shellam, G.R. Antibody responses to murine cytomegalovirus in genetically resistant and susceptible strains of mice. J. Gen. Virol. 1988, 69, 1987-1998. [CrossRef] [PubMed]

113. Bootz, A.; Karbach, A.; Spindler, J.; Kropff, B.; Reuter, N.; Sticht, H.; Winkler, T.H.; Britt, W.J.; Mach, M. Protective capacity of neutralizing and non-neutralizing antibodies against glycoprotein B of cytomegalovirus. PLoS Pathog. 2017, 13, e1006601. [CrossRef] [PubMed]

114. Kenneson, A.; Cannon, M.J. Review and meta-analysis of the epidemiology of congenital cytomegalovirus (CMV) infection. Rev. Med. Virol. 2007, 17, 253-276. [CrossRef] [PubMed] 
115. Iwasenko, J.M.; Howard, J.; Arbuckle, S.; Graf, N.; Hall, B.; Craig, M.E.; Rawlinson, W.D. Human cytomegalovirus infection is detected frequently in stillbirths and is associated with fetal thrombotic vasculopathy. J. Infect. Dis. 2011, 203, 1526-1533. [CrossRef] [PubMed]

116. Leyder, M.; Vorsselmans, A.; Done, E.; Van Berkel, K.; Faron, G.; Foulon, I.; Naessens, A.; Jansen, A.; Foulon, W.; Gucciardo, L. Primary maternal cytomegalovirus infections: Accuracy of fetal ultrasound for predicting sequelae in offspring. Am. J. Obstet. Gynecol. 2016, 215, 638.e1-638.e8. [CrossRef] [PubMed]

117. Enders, G.; Daiminger, A.; Bader, U.; Exler, S.; Enders, M. Intrauterine transmission and clinical outcome of 248 pregnancies with primary cytomegalovirus infection in relation to gestational age. J. Clin. Virol. 2011, 52, 244-246. [CrossRef]

118. Kylat, R.I.; Kelly, E.N.; Ford-Jones, E.L. Clinical findings and adverse outcome in neonates with symptomatic congenital cytomegalovirus (SCCMV) infection. Eur. J. Pediatr. 2006, 165, 773-778. [CrossRef]

119. Nigro, G. Maternal-fetal cytomeglaovirus infection: From diagnosis to therapy. J. Matern. Fetal Neonatal Med. 2009, 22, 169-174. [CrossRef]

120. Medearis, D.N.; Campbell, F.; Arnold, P. Mouse Cytomegalovirus infection III. Attempts to produce intrauterine infections. Am. J. Hygeine 1964, 80, 113-120.

121. Schleiss, M.R.; Mcvoy, M.A. Guinea pig cytomegalovirus: A model for the prevention and treatment of maternal-fetal cytomegalovirus transmission. Future Virol. 2010, 5, 207-217. [CrossRef]

122. Johnson, K.P. Mouse cytomegalovirus: Placental infection. J. Infect. Dis. 1969, 120, 445-450. [CrossRef] [PubMed]

123. Lansdown, A.B.; Brown, J.D. Pathological observations on experimental cytomegalovirus infections in pregnancy. J. Pathol. 1978, 125, 1-9. [CrossRef] [PubMed]

124. Baskar, J.F.; Peacock, J.; Sulik, K.K.; Huang, E.S. Early-stage developmental abnormalities induced by murine cytomegalovirus. J. Infect. Dis. 1987, 155, 661-666. [CrossRef] [PubMed]

125. Fitzgerald, N.A.; Shellam, G.R. Host genetic influences on fetal susceptibility to murine cytomegalovirus after maternal or fetal infection. J. Infect. Dis. 1991, 163, 276-281. [CrossRef]

126. Tsutsui, Y. Developmental Disorders of the Mouse-Brain Induced by Murine Cytomegalovirus-Animal-Models for Congenital Cytomegalovirus-Infection. Pathol. Int. 1995, 45, 91-102. [CrossRef]

127. Tsutsui, Y.; Kashiwai, A.; Kawamura, N.; Aibamasago, S.; Kosugi, I. Prolonged Infection of Mouse-Brain Neurons with Murine Cytomegalovirus after Prenatal and Perinatal Infection. Arch. Virol. 1995, 140, 1725-1736. [CrossRef]

128. Li, R.Y.; Tsutsui, Y. Growth retardation and microcephaly induced in mice by placental infection with murine cytomegalovirus. Teratology 2000, 62, 79-85. [CrossRef]

129. Woolf, N.K.; Jaquish, D.V.; Koehrn, F.J. Transplacental murine cytomegalovirus infection in the brain of SCID mice. Virol. J. 2007, 4, 26. [CrossRef]

130. Cekinovic, D.; Golemac, M.; Pugel, E.P.; Tomac, J.; Cicin-Sain, L.; Slavuljica, I.; Bradford, R.; Misch, S.; Winkler, T.H.; Mach, M.; et al. Passive Immunization Reduces Murine Cytomegalovirus-Induced Brain Pathology in Newborn Mice. J. Virol. 2008, 82, 12172-12180. [CrossRef]

131. Slavuljica, I.; Kveštak, D.; Huszthy, P.C.; Kosmac, K.; Britt, W.J.; Jonjić, S. Immunobiology of congenital cytomegalovirus infection of the central nervous system-the murine cytomegalovirus model. Cell Mol. Immunol. 2015, 12, 180-191. [CrossRef]

132. Sung, C.Y.W.; Seleme, M.C.; Payne, S.; Jonjic, S.; Hirose, K.; Britt, W. Virus-induced cochlear inflammation in newborn mice alters auditory function. JCI Insight 2019, 4, e128878. [CrossRef] [PubMed]

133. Li, L.; Kosugi, I.; Han, G.P.; Kawasaki, H.; Arai, Y.; Takeshita, T.; Tsutsui, Y. Induction of cytomegalovirus-infected labyrinthitis in newborn mice by lipopolysaccharide: A model for hearing loss in congenital CMV infection. Lab. Investig. 2008, 88, 722-730. [CrossRef] [PubMed]

134. Gombos, R.B.; Wolan, V.; McDonald, K.; Hemmings, D.G. Impaired vascular function in mice with an active cytomegalovirus infection. Am. J. Physiol. Heart Circ. Physiol. 2009, 296, 937-945. [CrossRef] [PubMed]

135. Ikuta, K.; Ogawa, H.; Hashimoto, H.; Okano, W.; Tani, A.; Sato, E.; Kosugi, I.; Kobayashi, T.; Omori, K.; Suzutani, T. Restricted infection of murine cytomegalovirus (MCMV) in neonatal mice with MCMV-induced sensorineural hearing loss. J. Clin. Virol. 2015, 69, 138-145. [CrossRef] [PubMed]

136. Liao, Y.; Zhang, Y.N.; Liu, X.L.; Lu, Y.Y.; Zhang, L.L.; Xi, T.; Shu, S.N.; Fang, F. Maternal Murine Cytomegalovirus Infection during Pregnancy Up-regulates the Gene Expression of Toll-like Receptor 2 and 4 in Placenta. Curr. Med. Sci. 2018, 38, 632-639. [CrossRef] [PubMed]

137. Georgiades, P.; Ferguson-Smith, A.C.; Burton, G.J. Comparative developmental anatomy of the murine and human definitive placentae. Placenta 2002, 23, 3-19. [CrossRef]

138. Rossant, J.; Cross, J.C. Placental development: Lessons from mouse mutants. Nat. Rev. Genet. 2001, 2, 538-548. [CrossRef]

139. Smith, M.G. Propagation of Salivary Gland Virus of the mouse in Tissue Cultures. Proc. Soc. Exp. Biol. Med. 1954, 86, 433-440. [CrossRef]

140. La Torre, R.; Nigro, G.; Mazzocco, M.; Best, A.M.; Adler, S.P. Placental enlargement in women with primary maternal cytomegalovirus infection is associated with fetal and neonatal disease. Clin. Infect. Dis. 2006, 43, 994-1000. [CrossRef]

141. Tsutsui, Y. Effects of cytomegalovirus infection on embryogenesis and brain development. Congenit. Anom. 2009, 49, 47-55. [CrossRef] 
142. Tsutsui, Y.; Kosugi, I.; Kawasaki, H.; Arai, Y.; Han, G.P.; Li, L.; Kaneta, M. Roles of neural stem progenitor cells in cytomegalovirus infection of the brain in mouse models. Pathol. Int. 2008, 58, 257-267. [CrossRef] [PubMed]

143. Brizić, I.; Hiršl, L.; Šustić, M.; Golemac, M.; Britt, W.J.; Krmpotić, A.; Jonjić, S. CD4 T cells are required for maintenance of CD8 T(RM) cells and virus control in the brain of MCMV-infected newborn mice. Med. Microbiol. Immunol. 2019, 208, 487-494. [CrossRef] [PubMed]

144. Bantug, G.R.B.; Cekinovic, D.; Bradford, R.; Koontz, T.; Jonjic, S.; Britt, W.J. CD8+ T Lymphocytes Control Murine Cytomegalovirus Replication in the Central Nervous System of Newborn Animals. J. Immunol. 2008, 181, 2111-2123. [CrossRef] [PubMed]

145. Tsutsui, Y.; Kawasaki, H.; Kosugi, I. Reactivation of latent cytomegalovirus infection in mouse brain cells detected after transfer to brain slice cultures. J. Virol. 2002, 76, 7247-7254. [CrossRef] 